\title{
Aqueous-phase mechanism for secondary organic aerosol formation from isoprene: application to the southeast United States and co-benefit of $\mathrm{SO}_{2}$ emission controls
}

\author{
E. A. Marais ${ }^{1}$, D. J. Jacob ${ }^{1,2}$, J. L. Jimenez ${ }^{3,4}$, P. Campuzano-Jost ${ }^{3,4}$, D. A. Day ${ }^{3,4}$, W. Hu ${ }^{3,4}$, J. Krechmer ${ }^{3,4}$, L. Zhu ${ }^{1}$,

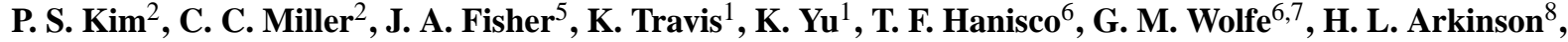

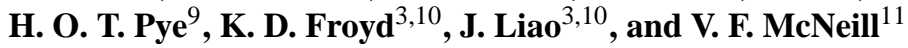 \\ ${ }^{1}$ School of Engineering and Applied Sciences, Harvard University, Cambridge, MA, USA \\ ${ }^{2}$ Earth and Planetary Sciences, Harvard University, Cambridge, MA, USA \\ ${ }^{3}$ Cooperative Institute for Research in Environmental Sciences, University of Colorado, Boulder, CO, USA \\ ${ }^{4}$ Department of Chemistry and Biochemistry, University of Colorado, Boulder, CO, USA \\ ${ }^{5}$ School of Chemistry and School of Earth and Environmental Sciences, University of Wollongong, Wollongong, \\ New South Wales, Australia \\ ${ }^{6}$ Atmospheric Chemistry and Dynamics Lab, NASA Goddard Space Flight Center, Greenbelt, MD, USA \\ ${ }^{7}$ Joint Center for Earth Systems Technology, University of Maryland Baltimore County, Baltimore, MD, USA \\ ${ }^{8}$ Department of Atmospheric and Oceanic Science, University of Maryland, College Park, MD, USA \\ ${ }^{9}$ National Exposure Research Laboratory, US EPA, Research Triangle Park, NC, USA \\ ${ }^{10}$ Chemical Sciences Division, Earth System Research Laboratory, NOAA, Boulder, CO, USA \\ ${ }^{11}$ Department of Chemical Engineering, Columbia University, New York, NY, USA \\ Correspondence to: E. A. Marais (emarais@seas.harvard.edu)
}

Received: 21 October 2015 - Published in Atmos. Chem. Phys. Discuss.: 13 November 2015

Revised: 25 January 2016 - Accepted: 31 January 2016 - Published: 11 February 2016

\begin{abstract}
Isoprene emitted by vegetation is an important precursor of secondary organic aerosol (SOA), but the mechanism and yields are uncertain. Aerosol is prevailingly aqueous under the humid conditions typical of isoprene-emitting regions. Here we develop an aqueous-phase mechanism for isoprene SOA formation coupled to a detailed gas-phase isoprene oxidation scheme. The mechanism is based on aerosol reactive uptake coefficients $(\gamma)$ for water-soluble isoprene oxidation products, including sensitivity to aerosol acidity and nucleophile concentrations. We apply this mechanism to simulation of aircraft (SEAC ${ }^{4} \mathrm{RS}$ ) and ground-based (SOAS) observations over the southeast US in summer 2013 using the GEOS-Chem chemical transport model. Emissions of nitrogen oxides $\left(\mathrm{NO}_{x} \equiv \mathrm{NO}+\mathrm{NO}_{2}\right)$ over the southeast US are such that the peroxy radicals produced from isoprene oxidation $\left(\mathrm{ISOPO}_{2}\right)$ react significantly with both $\mathrm{NO}$ (high- $\mathrm{NO}_{x}$ pathway) and $\mathrm{HO}_{2}$ (low- $\mathrm{NO}_{x}$ pathway), leading to different suites of isoprene SOA precursors. We find a mean SOA mass yield of $3.3 \%$ from isoprene oxidation, consistent with
\end{abstract}

the observed relationship of total fine organic aerosol (OA) and formaldehyde (a product of isoprene oxidation). Isoprene SOA production is mainly contributed by two immediate gasphase precursors, isoprene epoxydiols (IEPOX, $58 \%$ of isoprene SOA) from the low- $\mathrm{NO}_{x}$ pathway and glyoxal $(28 \%)$ from both low- and high- $\mathrm{NO}_{x}$ pathways. This speciation is consistent with observations of IEPOX SOA from SOAS and SEAC ${ }^{4} \mathrm{RS}$. Observations show a strong relationship between IEPOX SOA and sulfate aerosol that we explain as due to the effect of sulfate on aerosol acidity and volume. Isoprene SOA concentrations increase as $\mathrm{NO}_{x}$ emissions decrease (favoring the low- $\mathrm{NO}_{x}$ pathway for isoprene oxidation), but decrease more strongly as $\mathrm{SO}_{2}$ emissions decrease (due to the effect of sulfate on aerosol acidity and volume). The US Environmental Protection Agency (EPA) projects 2013-2025 decreases in anthropogenic emissions of $34 \%$ for $\mathrm{NO}_{x}$ (leading to a $7 \%$ increase in isoprene $\mathrm{SOA})$ and $48 \%$ for $\mathrm{SO}_{2}(35 \%$ decrease in isoprene $\mathrm{SOA})$. Reducing $\mathrm{SO}_{2}$ emissions decreases sulfate and isoprene SOA by a similar magnitude, represent- 
ing a factor of 2 co-benefit for $\mathrm{PM}_{2.5}$ from $\mathrm{SO}_{2}$ emission controls.

\section{Introduction}

Isoprene emitted by vegetation is a major source of secondary organic aerosol (SOA) (Carlton et al., 2009, and references therein) with effects on human health, visibility, and climate. There is large uncertainty in the yield and composition of isoprene SOA (Scott et al., 2014; McNeill et al., 2014), involving a cascade of species produced in the gasphase oxidation of isoprene and their interaction with preexisting aerosol (Hallquist et al., 2009). We develop here a new aqueous-phase mechanism for isoprene SOA formation coupled to gas-phase chemistry, implement it in the GEOSChem chemical transport model (CTM) to simulate observations in the southeast US, and from there derive new constraints on isoprene SOA yields and the contributing pathways.

Organic aerosol is ubiquitous in the atmosphere, often dominating fine aerosol mass (Zhang et al., 2007), including in the southeast US where it accounts for more than $60 \%$ in summer (Attwood et al., 2014). It may be directly emitted by combustion as primary organic aerosol (POA), or produced within the atmosphere as SOA by oxidation of volatile organic compounds (VOCs). Isoprene $\left(\mathrm{C}_{5} \mathrm{H}_{8}\right)$ from vegetation is the dominant VOC emitted globally, and the southeast US in summer is one of the largest isoprene-emitting regions in the world (Guenther et al., 2006). SOA yields from isoprene are low compared with larger VOCs (Pye et al., 2010), but isoprene emissions are much higher. Kim et al. (2015) estimated that isoprene accounts for $40 \%$ of total organic aerosol in the southeast US in summer.

Formation of OA from oxidation of isoprene depends on local concentrations of nitrogen oxide radicals $\left(\mathrm{NO}_{x} \equiv \mathrm{NO}+\mathrm{NO}_{2}\right)$ and pre-existing aerosol. $\mathrm{NO}_{x}$ concentrations determine the fate of organic peroxy radicals originating from isoprene oxidation $\left(\mathrm{ISOPO}_{2}\right)$, leading to different cascades of oxidation products in the low- $\mathrm{NO}_{x}$ and high$\mathrm{NO}_{x}$ pathways (Paulot et al., 2009a, b). Uptake of isoprene oxidation products to the aerosol phase depends on their vapor pressure (Donahue et al., 2006), solubility in aqueous media (Saxena and Hildeman, 1996), and subsequent condensed-phase reactions (Volkamer et al., 2007). Aqueous aerosol provides a medium for reactive uptake (Eddingsaas et al., 2010; Surratt et al., 2010) with dependences on acidity (Surratt et al., 2007a), concentration of nucleophiles such as sulfate (Surratt et al., 2007b), aerosol water (Carlton and Turpin, 2013), and organic coatings (Gaston et al., 2014).

We compile in Fig. 1 the published laboratory yields of isoprene SOA as a function of initial NO concentration and relative humidity $(\mathrm{RH})$. Here and elsewhere, the isoprene SOA yield is defined as the mass of SOA produced per unit mass of isoprene oxidized. Isoprene SOA yields span a wide range, from $<0.1 \%$ to $>10 \%$, with no systematic difference between low- $\mathrm{NO}_{x}$ and high- $\mathrm{NO}_{x}$ pathways. Yields tend to be higher in dry chambers $(\mathrm{RH}<10 \%)$. Under such dry conditions isoprene SOA is expected to be solid (Virtanen et al., 2010; Song et al., 2015). At humid conditions more representative of the summertime boundary layer, aerosols are likely aqueous (Bateman et al., 2014). Standard isoprene SOA mechanisms used in atmospheric models assume reversible partitioning onto pre-existing organic aerosol, fitting the dry chamber data (Odum et al., 1996). However, this may not be appropriate for actual atmospheric conditions where aqueous-phase chemistry with irreversible reactive uptake of water-soluble gases is likely the dominant mechanism (Ervens et al., 2011; Carlton and Turpin, 2013). Several regional/global models have implemented mechanisms for aqueous-phase formation of isoprene SOA (Fu et al., 2008, 2009; Carlton et al., 2008; Myriokefalitakis et al., 2011; Liu et al., 2012; Pye et al., 2013; Lin et al., 2014).

Here we present a mechanism for irreversible aqueousphase isoprene SOA formation integrated within a detailed chemical mechanism for isoprene gas-phase oxidation, thus linking isoprene SOA formation to gas-phase chemistry and avoiding more generic volatility-based parameterizations that assume dry organic aerosol (Odum et al., 1996; Donahue et al., 2006). We use this mechanism in the GEOS-Chem CTM to simulate observations from the SOAS (surface) and SEAC ${ }^{4} \mathrm{RS}$ (aircraft) field campaigns over the southeast US in summer 2013, with focus on isoprene SOA components and on the relationship between $\mathrm{OA}$ and formaldehyde (HCHO). $\mathrm{HCHO}$ is a high-yield oxidation product of isoprene (Palmer et al., 2003) and we use the OA-HCHO relationship as a constraint on isoprene SOA yields. SOAS measurements were made at a ground site in rural Centreville, Alabama (Hu et al., 2015; http://soas2013.rutgers.edu/). SEAC ${ }^{4} \mathrm{RS}$ measurements were made from the NASA DC-8 aircraft with extensive boundary-layer coverage across the southeast (Toon and the SEAC ${ }^{4}$ RS science team, 2016; SEAC ${ }^{4}$ RS Archive, 2015).

\section{Chemical mechanism for isoprene SOA formation}

The default treatment of isoprene SOA in GEOS-Chem at the time of this work (v9-02; http://geos-chem.org) followed a standard parameterization operating independently from the gas-phase chemistry mechanism and based on reversible partitioning onto pre-existing OA of generic semivolatile products of isoprene oxidation by $\mathrm{OH}$ and $\mathrm{NO}_{3}$ radicals (Pye et al., 2010). Here we implement a new mechanism for reactive uptake by aqueous aerosols of species produced in the isoprene oxidation cascade of the GEOS-Chem gas-phase mechanism. This couples SOA formation to the gas-phase chemistry and is in accord with increased evidence for a major role of aqueous aerosols in isoprene SOA formation (Ervens et al., 2011). 


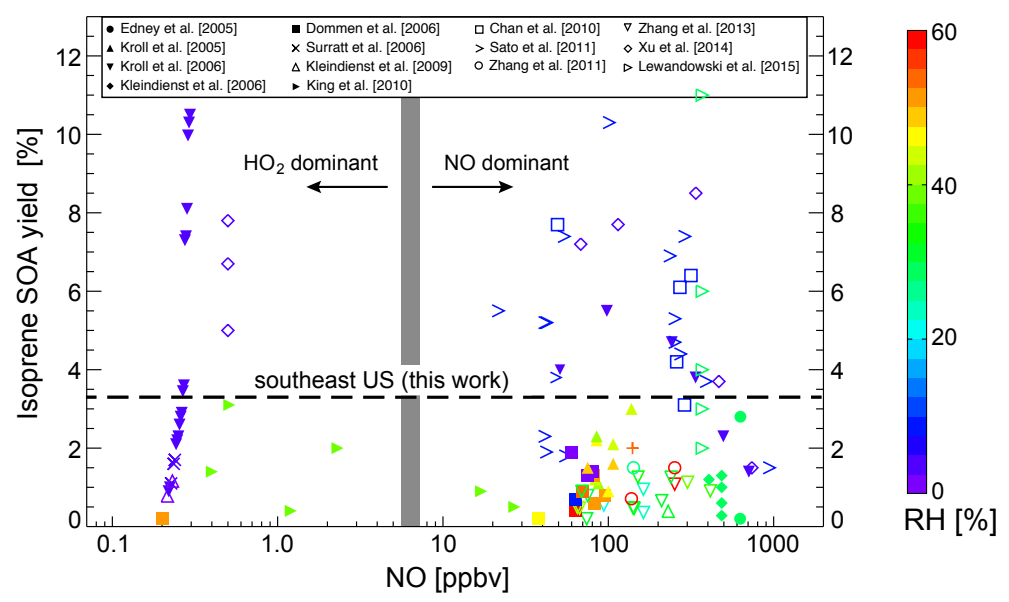

Figure 1. Yields of secondary organic aerosol (SOA) from isoprene oxidation as reported by chamber studies in the literature and plotted as a function of the initial NO concentration and relative humidity (RH). Yields are defined as the mass of SOA produced per unit mass of isoprene oxidized. For studies with no detectable NO we plot the NO concentration as half the reported instrument detection limit, and stagger points as needed for clarity. Data are colored by relative humidity (RH). The thick gray line divides the low- $\mathrm{NO}_{x}$ and high-NO$x$ pathways as determined by the fate of the $\mathrm{ISOPO}_{2}$ radical $\left(\mathrm{HO}_{2}\right.$ dominant for the low- $\mathrm{NO}_{x}$ pathway, $\mathrm{NO}$ dominant for the high-NO $\mathrm{N}_{x}$ pathway). The transition between the two pathways occurs at a higher $\mathrm{NO}$ concentration than in the atmosphere because $\mathrm{HO}_{2}$ concentrations in the chambers are usually much higher. Also shown as a dashed line is the mean atmospheric yield of $3.3 \%$ for the southeast US determined in our study.

The standard gas-phase isoprene oxidation mechanism in GEOS-Chem v9-02 is described in Mao et al. (2013) and is based on best knowledge at the time building on mechanisms for the oxidation of isoprene by $\mathrm{OH}$ (Paulot et al., 2009a, b) and $\mathrm{NO}_{3}$ (Rollins et al., 2009). Updates implemented in this work are described below and in companion papers applying GEOS-Chem to simulation of observed gas-phase isoprene oxidation products over the southeast US in summer 2013 (Fisher et al., 2016; Travis et al., 2016). Most gas-phase products of the isoprene oxidation cascade in GEOS-Chem have high dry deposition velocity, competing in some cases with removal by oxidation and aerosol formation (Nguyen et al., 2015a; Travis et al., 2016).

Figure 2 shows the isoprene oxidation cascade in GEOSChem leading to SOA formation. Reaction pathways leading to isoprene SOA precursors are described below. Yields are in mass percent, unless stated otherwise. Reactive $\mathrm{ISOPO}_{2}$ isomers formed in the first $\mathrm{OH}$ oxidation step react with $\mathrm{NO}$, the hydroperoxyl radical $\left(\mathrm{HO}_{2}\right)$, other peroxy radicals $\left(\mathrm{RO}_{2}\right)$, or undergo isomerization (Peeters et al., 2009). The NO reaction pathway (high- $\mathrm{NO}_{x}$ pathway) yields $\mathrm{C}_{5}$ hydroxy carbonyls, methyl vinyl ketone, methacrolein, and first-generation isoprene nitrates (ISOPN). The first three products go on to produce glyoxal and methylglyoxal, which serve as SOA precursors. The overall yield of glyoxal from the high- $\mathrm{NO}_{x}$ pathway is $7 \mathrm{~mol} \%$ (yield on a molar basis). Oxidation of ISOPN by $\mathrm{OH}$ and $\mathrm{O}_{3}$ is as described by Lee et al. (2014). Reaction of ISOPN with OH produces saturated dihydroxy dinitrates (DHDN), 21 and $27 \mathrm{~mol} \%$ from the beta and delta channels respectively (Lee et al., 2014), and $10 \mathrm{~mol} \%$ isoprene epoxydiols (IEPOX) from each chan- nel (Jacobs et al., 2014). We also adopt the mechanism of Lin et al. (2013) to generate $\mathrm{C}_{4}$ hydroxy epoxides (methacrylic acid epoxide and hydroxymethylmethyl- $\alpha$-lactone, both denoted MEPOX) from $\mathrm{OH}$ oxidation of a peroxyacyl nitrate, formed when methacrolein reacts with $\mathrm{OH}$ followed by $\mathrm{NO}_{2}$. Only hydroxymethylmethyl- $\alpha$-lactone is shown in Fig. 2.

The $\mathrm{HO}_{2}$ reaction pathway for $\mathrm{ISOPO}_{2}$ leads to formation of hydroxyhydroperoxides (ISOPOOH) that are oxidized to IEPOX (Paulot et al., 2009b) and several low-volatility products, represented here as $\mathrm{C}_{5}$-LVOC (Krechmer et al., 2015). The kinetics of IEPOX oxidation by $\mathrm{OH}$ is uncertain, and experimentally determined IEPOX lifetimes vary from 8 to $28 \mathrm{~h}$ for an $\mathrm{OH}$ concentration of $1 \times 10^{6}$ molecules $\mathrm{cm}^{-3}$ (Jacobs et al., 2013; Bates et al., 2014). In GEOS-Chem we apply the fast kinetics of Jacobs et al. (2013) and reduce the yield of IEPOX from ISOPOOH from 100 to $75 \%$, within the range observed by St. Clair et al. (2015), to address a factor of 4 overestimate in simulated IEPOX pointed out by Nguyen et al. (2015a). The IEPOX discrepancy could alternatively be addressed with an order-of-magnitude increase in uptake by aerosol (see below) but the model would then greatly overestimate the observed IEPOX SOA concentrations in SOAS and SEAC ${ }^{4}$ RS (Sect. 4).

IEPOX oxidizes to form glyoxal and methylglyoxal (Bates et al., 2014). The overall glyoxal yield from the $\mathrm{ISOPO}_{2}+\mathrm{HO}_{2}$ pathway is $6 \mathrm{~mol} \%$. Krechmer et al. (2015) report a $2.5 \mathrm{~mol} \%$ yield of $\mathrm{C}_{5}$-LVOC from ISOPOOH but we reduce this to $0.5 \mathrm{~mol} \%$ to reproduce surface observations of the corresponding aerosol products (Sect. 4). Methyl vinyl ketone and methacrolein yields from the $\mathrm{ISOPO}_{2}+\mathrm{HO}_{2}$ pathway are 2.5 and $3.8 \mathrm{~mol} \%$, respectively (Liu et al., 


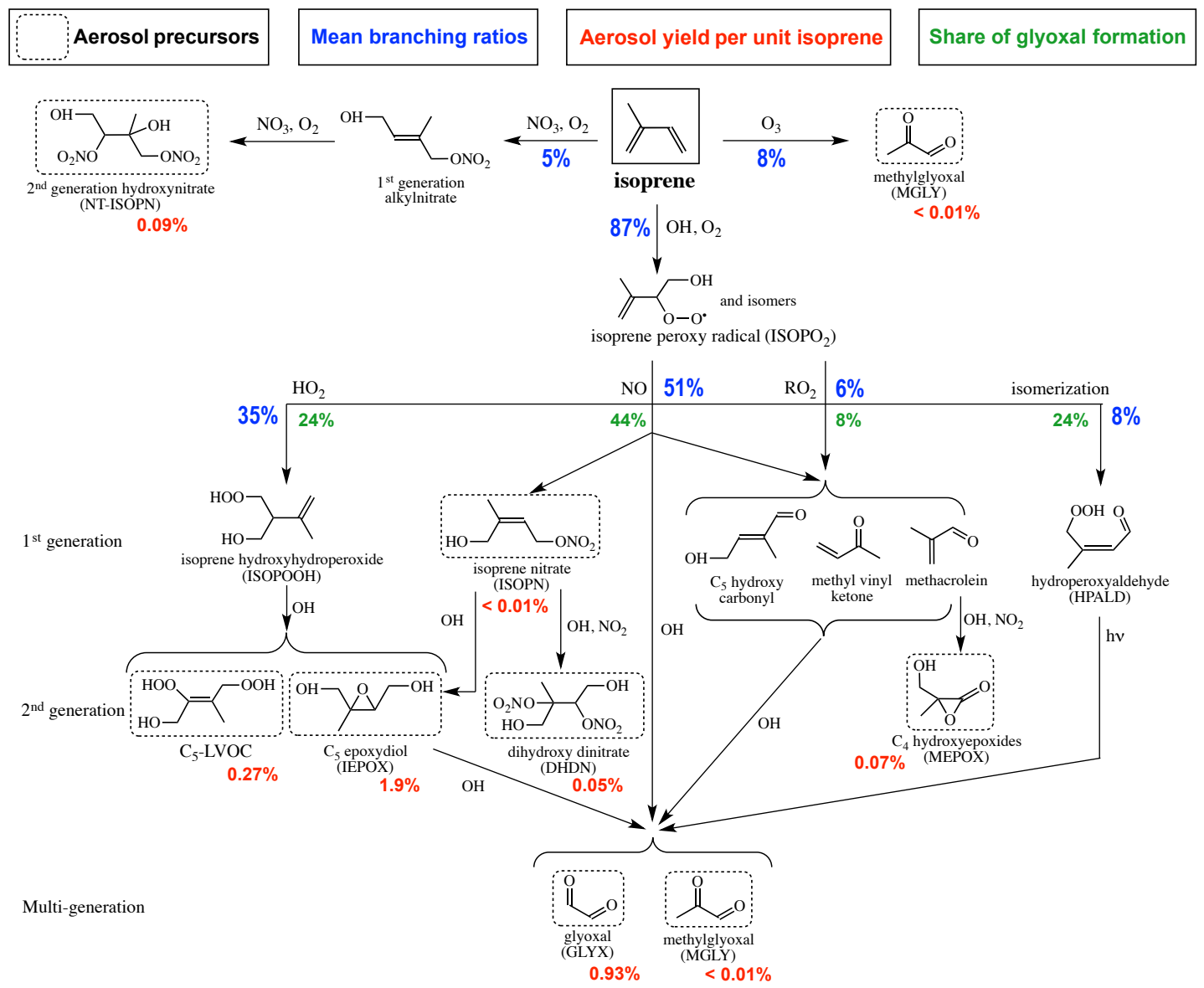

Figure 2. Gas-phase isoprene oxidation cascade in GEOS-Chem leading to secondary organic aerosol (SOA) formation by irreversible aqueous-phase chemistry. Only selected species relevant to SOA formation are shown. Immediate aerosol precursors are indicated by dashed boxes. Branching ratios and SOA yields (aerosol mass produced per unit mass isoprene reacted) are mean values from our GEOS-Chem simulation for the southeast US boundary layer in summer. The total SOA yield from isoprene oxidation is $3.3 \%$ and the values shown below the dashed boxes indicate the contributions from the different immediate precursors adding up to $3.3 \%$. Contributions of high- and low- $\mathrm{NO}_{x}$ isoprene oxidation pathways to glyoxal are indicated.

2013), sufficiently low that they do not lead to significant SOA formation.

Minor channels for $\mathrm{ISOPO}_{2}$ are isomerization and reaction with $\mathrm{RO}_{2}$. Isomerization forms hydroperoxy aldehydes (HPALD) that go on to photolyze, but products are uncertain (Peeters and Müller, 2010). We assume $25 \mathrm{~mol} \%$ yield each of glyoxal and methylglyoxal from HPALD photolysis in GEOS-Chem following Stavrakou et al. (2010). Reaction of $\mathrm{ISOPO}_{2}$ with $\mathrm{RO}_{2}$ leads to the same suite of $\mathrm{C}_{4}-$ $\mathrm{C}_{5}$ carbonyls as reaction with $\mathrm{NO}\left(\mathrm{C}_{5}\right.$ hydroxy carbonyls, methacrolein, and methyl vinyl ketone) and from there to glyoxal and methylglyoxal.

Immediate aerosol precursors from the isoprene $+\mathrm{OH}$ oxidation cascade are identified in Fig. 2. For the high- $\mathrm{NO}_{x}$ pathway (ISOPO$+2+\mathrm{NO}$ channel) these include glyoxal and methylglyoxal (McNeill et al., 2012), ISOPN (Darer et al., 2011; Hu et al., 2011), DHDN (Lee et al., 2014), MEPOX (Lin et al., 2013), and IEPOX (Jacobs et al., 2014). For the low- $\mathrm{NO}_{x}$ pathway (ISOPO $2+\mathrm{HO}_{2}$ channel) aerosol precursors are IEPOX (Eddingsaas et al., 2010), $\mathrm{C}_{5}$-LVOC (Krechmer et al., 2015, in which the aerosol-phase species is denoted ISOPOOH-SOA), glyoxal, and methylglyoxal. Glyoxal and methylglyoxal are also produced from the $\mathrm{ISOPO}_{2}+\mathrm{RO}_{2}$ and $\mathrm{ISOPO}_{2}$ isomerization channels.

Ozonolysis and oxidation by $\mathrm{NO}_{3}$ are additional minor isoprene reaction pathways (Fig. 2). The $\mathrm{NO}_{3}$ oxidation pathway is a potentially important source of isoprene SOA at night (Brown et al., 2009) from the irreversible uptake of low-volatility second-generation hydroxynitrates (NT-ISOPN) (Ng et al., 2008; Rollins et al., 2009). We update the gas-phase chemistry of Rollins et al. (2009) as implemented by Mao et al. (2013) to include formation of $4 \mathrm{~mol} \%$ of the aerosol-phase precursor NT-ISOPN from firstgeneration alkyl nitrates (Rollins et al., 2009). Ozonolysis products are volatile and observed SOA yields in chamber studies are low ( $<1 \%$; Kleindienst et al., 2007). In 
Table 1. Constants for reactive uptake of isoprene SOA precursors ${ }^{\mathrm{a}}$.

\begin{tabular}{llllll}
\hline Species $^{\mathrm{b}}$ & $H^{*}\left(\mathrm{M} \mathrm{atm}^{-1}\right)$ & $k_{\mathrm{H}^{+}}\left(\mathrm{M}^{-1} \mathrm{~s}^{-1}\right)$ & $k_{\mathrm{nuc}}\left(\mathrm{M}^{-2} \mathrm{~s}^{-1}\right)$ & $k_{\mathrm{HSO}_{4}^{-}}\left(\mathrm{M}^{-1} \mathrm{~s}^{-1}\right)$ & $k_{\mathrm{aq}}\left(\mathrm{s}^{-1}\right)$ \\
\hline IEPOX & $3.3 \times 10^{7, \mathrm{c}}$ & $3.6 \times 10^{-2, \mathrm{~d}}$ & $2.0 \times 10^{-4, \mathrm{e}}$ & $7.3 \times 10^{-4, \mathrm{e}}$ & Equation $(2)$ \\
ISOPN $_{\beta}^{\mathrm{f}}$ & $3.3 \times 10^{5, \mathrm{~g}}$ & - & - & - & $1.6 \times 10^{-5, \mathrm{~h}}$ \\
ISOPN $_{\delta}^{\mathrm{f}}$ & $3.3 \times 10^{5, \mathrm{~g}}$ & - & - & - & $6.8 \times 10^{-3, \mathrm{~h}}$ \\
DHDN $^{3.3 \times 10^{5, \mathrm{~g}}}$ & - & - & - & $6.8 \times 10^{-3, \mathrm{i}}$ \\
\hline
\end{tabular}

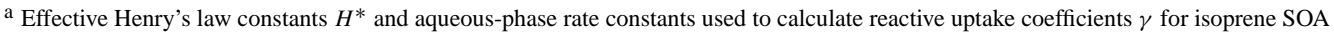
precursors IEPOX, ISOPN $\beta$, ISOPN $_{\delta}$, and DHDN following Eqs. (1) and (2). Calculation of $\gamma$ for other isoprene SOA precursors in Fig. 2 is described in the text. ${ }^{b}$ See Fig. 2 for definition of acronyms. ${ }^{c}$ Best fit to SOAS and SEAC ${ }^{4}$ RS IEPOX SOA and consistent with Nguyen et al. (2014). ${ }^{\mathrm{d}}$ Cole-Filipiak et al. (2010). ${ }^{\mathrm{e}}$ Eddingsaas et al. (2010). ${ }^{\mathrm{f}}$ ISOPN species formed from the beta and delta isoprene oxidation channels (Paulot et al., 2009a) are treated separately in GEOS-Chem. ${ }^{\mathrm{g}}$ By analogy with 4-nitrooxy-3-methyl-2-butanol (Rollins et al., 2009). ${ }^{\mathrm{h}}$ Jacobs et al. (2014). ${ }^{\mathrm{i}}$ Assumed the same as for $\mathrm{ISOPN}_{\delta}$ (Hu et al., 2011).

GEOS-Chem only methylglyoxal is an aerosol precursor from isoprene ozonolysis.

We implement uptake of isoprene oxidation products to aqueous aerosols using laboratory-derived reactive uptake coefficients $(\gamma)$ as given by Anttila et al. (2006) and Gaston et al. (2014):

$\gamma=\left[\frac{1}{\alpha}+\frac{3 \omega}{4 r R T H^{*} k_{\mathrm{aq}}}\right]^{-1}$.

Here $\alpha$ is the mass accommodation coefficient (taken as 0.1 for all immediate SOA precursors in Fig. 2), $\omega$ is the mean gas-phase molecular speed $\left(\mathrm{cm} \mathrm{s}^{-1}\right), r$ is the aqueous particle radius $(\mathrm{cm}), R$ is the universal gas constant $\left(0.08206 \mathrm{~L} \mathrm{~atm} \mathrm{~K}^{-1} \mathrm{~mol}^{-1}\right), T$ is temperature $(\mathrm{K}), H^{*}$ is the effective Henry's Law constant $\left(\mathrm{M} \mathrm{atm}^{-1}\right)$ accounting for any fast dissociation equilibria in the aqueous phase, and $k_{\text {aq }}$ is the pseudo-first-order aqueous-phase reaction rate constant $\left(\mathrm{s}^{-1}\right)$ for conversion to non-volatile products.

Precursors with epoxide functionality, IEPOX and MEPOX, undergo acid-catalyzed epoxide ring opening and nucleophilic addition in the aqueous phase. The aqueousphase rate constant formulation is from Eddingsaas et al. (2010),

$k_{\mathrm{aq}}=k_{\mathrm{H}^{+}}\left[\mathrm{H}^{+}\right]+k_{\mathrm{nuc}}[\mathrm{nuc}]\left[\mathrm{H}^{+}\right]+k_{\mathrm{HSO}_{4}^{-}}\left[\mathrm{HSO}_{4}^{-}\right]$,

and includes three channels: acid-catalyzed ring opening followed by nucleophilic addition of $\mathrm{H}_{2} \mathrm{O}\left(k_{\mathrm{H}^{+}}\right.$in $\left.\mathrm{M}^{-1} \mathrm{~s}^{-1}\right)$ leading to methyltetrols, acid-catalyzed ring opening followed by nucleophilic addition of sulfate and nitrate ions (nuc $\equiv \mathrm{SO}_{4}^{2-}+\mathrm{NO}_{3}^{-}, k_{\text {nuc }}$ in $\mathrm{M}^{-2} \mathrm{~s}^{-1}$ ) leading to organosulfates and organonitrates, and concerted protonation and nucleophilic addition by bisulfate, $\mathrm{HSO}_{4}^{-}\left(k_{\mathrm{HSO}_{4}^{-}}\right.$in $\left.\mathrm{M}^{-1} \mathrm{~s}^{-1}\right)$, leading to organosulfates.

Precursors with nitrate functionality $\left(-\mathrm{ONO}_{2}\right)$, ISOPN and DHDN, hydrolyze to form low-volatility polyols and nitric acid (Hu et al., 2011; Jacobs et al., 2014), so $k_{\text {aq }}$ in Eq. (1) is the hydrolysis rate constant.

Glyoxal and methylglyoxal form SOA irreversibly by surface uptake followed by aqueous-phase oxidation and oligomerization to yield non-volatile products (Liggio et al., 2005; Volkamer et al., 2009; Nozière et al., 2009; Ervens et al., 2011; Knote et al., 2014). Glyoxal forms SOA with higher yields during the day than at night due to $\mathrm{OH}$ aqueousphase chemistry (Tan et al., 2009; Volkamer et al., 2009; Sumner et al., 2014). We use a daytime $\gamma$ of $2.9 \times 10^{-3}$ for glyoxal from Liggio et al. (2005) and a nighttime $\gamma$ of $5 \times 10^{-6}$ (Waxman et al., 2013; Sumner et al., 2014). The SOA yield of methylglyoxal is small compared with that of glyoxal (McNeill et al., 2012). A previous GEOS-Chem study by Fu et al. (2008) used the same $\gamma\left(2.9 \times 10^{-3}\right)$ for glyoxal and methylglyoxal. Reaction rate constants are similar for aqueous-phase processing of glyoxal and methylglyoxal (Buxton et al., 1997; Ervens et al., 2003), but $H^{*}$ of glyoxal is about 4 orders of magnitude higher. Here we scale the $\gamma$ for methylglyoxal to the ratio of effective Henry's law constants: $H^{*}=3.7 \times 10^{3} \mathrm{M} \mathrm{atm}^{-1}$ for methylglyoxal (Tan et al., 2010) and $H^{*}=2.7 \times 10^{7} \mathrm{M} \mathrm{atm}^{-1}$ for glyoxal (Sumner et al., 2014). The resulting uptake of methylglyoxal is very slow and makes a negligible contribution to isoprene SOA.

The species $\mathrm{C}_{5}$-LVOC from ISOPOOH oxidation and NTISOPN from isoprene reaction with $\mathrm{NO}_{3}$ have very low volatility and are assumed to condense to aerosols with a $\gamma$ of 0.1 limited by mass accommodation. Results are insensitive to the precise value of $\gamma$ since uptake by aerosols is the main sink for these species in any case.

Table 1 gives input variables used to calculate $\gamma$ for IEPOX, ISOPN, and DHDN by Eqs. (1) and (2). Rate constants are from experiments in concentrated media, representative of aqueous aerosols, so no activity correction factors are applied. Reported experimental values of $k_{\mathrm{H}^{+}}$vary by an order of magnitude from $1.2 \times 10^{-3} \mathrm{M}^{-1} \mathrm{~s}^{-1}$ (Eddingsaas et al., 2010) to $3.6 \times 10^{-2} \mathrm{M}^{-1} \mathrm{~s}^{-1}$ (Cole-Filipiak et al., 2010). Values of $k_{\text {nuc }}$ vary by 3 orders of magnitude from $2 \times 10^{-4} \mathrm{M}^{-2} \mathrm{~s}^{-1}$ (Eddingsaas et al., 2010) to $5.2 \times 10^{-1} \mathrm{M}^{-2} \mathrm{~s}^{-1}$ (Piletic et al., 2013). Reported values of IEPOX $H^{*}$ vary by 2 orders of magnitude (Eddingsaas et al., 2010; Nguyen et al., 2014). We chose values of $k_{\mathrm{H}^{+}}, k_{\text {nuc }}$, and $H^{*}$ to fit the SOAS and SEAC ${ }^{4}$ RS observations of to- 
Table 2. Mean reactive uptake coefficients $\gamma$ of isoprene SOA precursors ${ }^{\mathrm{a}}$.

\begin{tabular}{|c|c|c|c|c|c|}
\hline \multirow[t]{2}{*}{ Species $^{b}$} & \multirow[t]{2}{*}{$\gamma$} & \multicolumn{4}{|c|}{$\mathrm{pH}$ dependence $\mathrm{c}^{\mathrm{c}}$} \\
\hline & & $\mathrm{pH}>3$ & $2<\mathrm{pH}<3$ & $1<\mathrm{pH}<2$ & $0<\mathrm{pH}<1$ \\
\hline IEPOX & $4.2 \times 10^{-3}$ & $8.6 \times 10^{-7}$ & $2.0 \times 10^{-4}$ & $1.1 \times 10^{-3}$ & $1.0 \times 10^{-2}$ \\
\hline MEPOX & $1.3 \times 10^{-4}$ & $2.7 \times 10^{-8}$ & $6.4 \times 10^{-6}$ & $3.6 \times 10^{-5}$ & $3.2 \times 10^{-4}$ \\
\hline $\operatorname{ISOPN}_{\beta}$ & $1.3 \times 10^{-7}$ & \multicolumn{4}{|c|}{ - } \\
\hline $\mathrm{ISOPN}_{\delta}$ & $5.2 \times 10^{-5}$ & \multicolumn{4}{|c|}{ - } \\
\hline DHDN & $6.5 \times 10^{-5}$ & \multicolumn{4}{|c|}{-} \\
\hline GLYX & $2.9 \times 10^{-3, d}$ & \multicolumn{4}{|c|}{-} \\
\hline MGLY & $4.0 \times 10^{-7}$ & \multicolumn{4}{|c|}{-} \\
\hline $\mathrm{C}_{5}$-LVOC & 0.1 & \multicolumn{4}{|c|}{-} \\
\hline NT-ISOPN & 0.1 & \multicolumn{4}{|c|}{-} \\
\hline
\end{tabular}

a Mean values computed in GEOS-Chem for the southeast US in summer as sampled along the boundary-layer $(<2 \mathrm{~km}) \mathrm{SEAC}^{4} \mathrm{RS}$ aircraft tracks and applied to aqueous aerosol. The reactive uptake coefficient $\gamma$ is defined as the probability that a gas molecule colliding with an aqueous aerosol particle will be taken up and react in the aqueous phase to form non-volatile products. ${ }^{\mathrm{b}}$ See Fig. 2 for definition of acronyms. ${ }^{\mathrm{c}} \gamma$ for IEPOX and MEPOX are continuous functions of $\mathrm{pH}$ (Eq. 2). Values shown here are averages for different $\mathrm{pH}$ ranges sampled along the $\mathrm{SEAC}^{4} \mathrm{RS}$ flight tracks. Aqueous aerosol $\mathrm{pH}$ is calculated locally in GEOS-Chem using the ISORROPIA thermodynamic model (Fountoukis and Nenes, 2007). ${ }^{\mathrm{d}}$ Daytime value. Nighttime value is $5 \times 10^{-6}$.

tal IEPOX SOA and IEPOX organosulfates, as discussed in Sect. 4.

Table 2 lists average values of $\gamma$ for all immediate aerosol precursors in the southeast US boundary layer in summer as simulated by GEOS-Chem (Sect. 3). $\gamma$ for IEPOX is a strong function of $\mathrm{pH}$ and increases from $1 \times 10^{-4}$ to $1 \times 10^{-2}$ as $\mathrm{pH}$ decreases from 3 to 0 . Gaston et al. (2014) reported orderof-magnitude higher values of $\gamma$ for IEPOX, reflecting their use of a higher $H^{*}$, but this would lead in our model to an overestimate of IEPOX SOA observations (Sect. 4). The value of $\gamma$ for MEPOX is assumed to be 30 times lower than that of IEPOX when the aerosol is acidic $(\mathrm{pH}<4)$, due to slower acid-catalyzed ring opening (Piletic et al., 2013; Riedel et al., 2015). At $\mathrm{pH}>4$ we assume that $\gamma$ for IEPOX and MEPOX are the same (Riedel et al., 2015), but they are then very low.

Isoprene SOA formation in clouds is not considered here. Acid-catalyzed pathways would be slow. Observations show that the isoprene SOA yield in the presence of laboratorygenerated clouds is low (0.2-0.4\%; Brégonzio-Rozier et al., 2015). Wagner et al. (2015) found no significant production of SOA in boundary-layer clouds over the southeast US during $\mathrm{SEAC}^{4} \mathrm{RS}$.

\section{GEOS-Chem simulation and isoprene SOA yields}

Several companion papers apply GEOS-Chem to interpret SEAC ${ }^{4} R S$ and surface data over the southeast US in summer 2013 including Kim et al. (2015) for aerosols, Fisher et al. (2016) for organic nitrates, Travis et al. (2016) for ozone and $\mathrm{NO}_{x}$, and $\mathrm{Zhu}$ et al. (2016) for HCHO. These studies use a model version with $0.25^{\circ} \times 0.3125^{\circ}$ horizontal resolution over North America, nested within a $4^{\circ} \times 5^{\circ}$ global simula- tion. Here we use a $2^{\circ} \times 2.5^{\circ}$ global GEOS-Chem simulation with no nesting. Yu et al. (2016) found little difference between $0.25^{\circ} \times 0.3125^{\circ}$ and $2^{\circ} \times 2.5^{\circ}$ resolutions in simulated regional statistics for isoprene chemistry.

The reader is referred to Kim et al. (2015) for a general presentation of the model, the treatment of aerosol sources and sinks, and evaluation with southeast US aerosol observations; and to Travis et al. (2016) and Fisher et al. (2016) for presentation of gas-phase chemistry and comparisons with observed gas-phase isoprene oxidation products. Isoprene emission is from the MEGAN v2.1 inventory (Guenther et al., 2012). The companion papers decrease isoprene emission by $15 \%$ from the MEGAN v2.1 values to fit the HCHO data (Zhu et al., 2016), but this is not applied here.

Our SOA simulation differs from that of Kim et al. (2015). They assumed fixed 3 and 5\% mass yields of SOA from isoprene and monoterpenes, respectively, and parameterized SOA formation from anthropogenic and open fire sources as a kinetic irreversible process following Hodzic and Jimenez (2011). Here we use our new aqueous-phase mechanism for isoprene SOA coupled to gas-phase chemistry as described in Sect. 2, and otherwise use the semivolatile reversible partitioning scheme of Pye et al. (2010) for monoterpene, anthropogenic, and open fire SOA. Kim et al. (2015) found no systematic bias in detailed comparisons to OA measurements from SEAC ${ }^{4} \mathrm{RS}$ and from surface networks. We find a low bias, as shown below, because the reversible partitioning scheme yields low anthropogenic and open fire SOA concentrations.

Organic aerosol and sulfate contribute most of the aerosol mass over the southeast US in summer, while nitrate is negligibly small (Kim et al., 2015). GEOS-Chem uses the ISORROPIA thermodynamic model (Fountoukis and Nenes, 
2007) to simulate sulfate-nitrate-ammonium (SNA) aerosol composition, water content, and acidity as a function of local conditions. Simulated aerosol $\mathrm{pH}$ along the $\mathrm{SEAC}^{4} \mathrm{RS}$ flight tracks in the southeast US boundary layer averages 1.3 (interquartiles 0.92 and 1.8). The aerosol $\mathrm{pH}$ remains below 3 even when sulfate aerosol is fully neutralized by ammonia (Guo et al., 2015).

We consider that the aqueous aerosol population where isoprene SOA formation can take place is defined by the sulfate aerosol population. This assumes that all aqueous aerosol particles contain some sulfate, and that all sulfate is aqueous. Clear-sky RH measured from the aircraft in the southeast US boundary layer during SEAC ${ }^{4} \mathrm{RS}$ averaged $72 \pm 17 \%$, and the corresponding values in GEOS-Chem sampled along the flight tracks averaged $66 \pm 16 \%$. These RHs are sufficiently high that sulfate aerosol can reliably be expected to be aqueous (Wang et al., 2008). The rate of gas uptake by the sulfate aerosol is computed with the pseudofirst-order reaction rate constant $k_{\text {het }}\left(\mathrm{s}^{-1}\right)$ (Schwartz, 1986; Jacob, 2000):

$k_{\mathrm{het}}=\int_{0}^{\infty} 4 \pi r^{2}\left(\frac{r}{D_{\mathrm{g}}}+\frac{4}{\gamma \omega}\right)^{-1} n(r) \mathrm{d} r$,

where $D_{\mathrm{g}}$ is the gas-phase diffusion constant (taken to be $0.1 \mathrm{~cm}^{2} \mathrm{~s}^{-1}$ ) and $n(r)$ is the number size distribution of sulfate aerosol $\left(\mathrm{cm}^{-4}\right)$. The first and second terms in parentheses describe the limitations to gas uptake from gas-phase diffusion and aqueous-phase reaction, respectively.

The sulfate aerosol size distribution including RHdependent hygroscopic growth factors is from the Global Aerosol Data Set (GADS) of Koepke et al. (1997), as originally implemented in GEOS-Chem by Martin et al. (2003) and updated by Drury et al. (2010). The GADS size distribution compares well with observations over the eastern US in summer (Drury et al., 2010), including for SEAC ${ }^{4} \mathrm{RS}$ (Kim et al., 2015). We compute $n(r)$ locally in GEOS-Chem by taking the dry SNA mass concentration, converting from mass to volume with a dry aerosol mass density of $1700 \mathrm{~kg} \mathrm{~m}^{-3}$ (Hess et al., 1998), applying the aerosol volume to the dry sulfate size distribution in GADS, and then applying the GADS hygroscopic growth factors. We verified that the hygroscopic growth factors from GADS agree within $10 \%$ with those computed locally from ISORROPIA.

Figure 2 shows the mean branching ratios for isoprene oxidation in the southeast US boundary layer as calculated by GEOS-Chem. $87 \%$ of isoprene reacts with $\mathrm{OH}, 8 \%$ with ozone, and $5 \%$ with $\mathrm{NO}_{3}$. Oxidation of isoprene by $\mathrm{OH}$ produces $\mathrm{ISOPO}_{2}$ of which $51 \%$ reacts with NO (high-NO pathway), $35 \%$ reacts with $\mathrm{HO}_{2}, 8 \%$ isomerizes, and $6 \%$ reacts with other $\mathrm{RO}_{2}$ radicals.

Glyoxal is an aerosol precursor common to all isoprene $+\mathrm{OH}$ pathways in our mechanism with yields of $7 \mathrm{~mol} \%$ from the $\mathrm{ISOPO}_{2}+\mathrm{NO}$ pathway, $6 \mathrm{~mol} \%$ from $\mathrm{ISOPO}_{2}+\mathrm{HO}_{2}, 11 \mathrm{~mol} \%$ from $\mathrm{ISOPO}_{2}+\mathrm{RO}_{2}$, and
$25 \mathrm{~mol} \%$ from $\mathrm{ISOPO}_{2}$ isomerization. For the southeast US conditions we thus find that $44 \%$ of glyoxal is from the $\mathrm{ISOPO}_{2}+\mathrm{NO}$ pathway, $24 \%$ from $\mathrm{ISOPO}_{2}+\mathrm{HO}_{2}, 8 \%$ from $\mathrm{ISOPO}_{2}+\mathrm{RO}_{2}$, and $24 \%$ from $\mathrm{ISOPO}_{2}$ isomerization.

The mean total yield of isoprene SOA computed in GEOSChem for the southeast US boundary layer is 3.3\%, as shown in Fig. 2. IEPOX contributes $1.9 \%$ and glyoxal $0.9 \%$. The low- $\mathrm{NO}_{x}$ pathway involving $\mathrm{ISOPO}_{2}$ reaction with $\mathrm{HO}_{2}$ contributes $73 \%$ of the total isoprene SOA yield, mostly from IEPOX, even though this pathway is only $35 \%$ of the fate of $\mathrm{ISOPO}_{2}$. The high-NO $\mathrm{NO}_{x}$ pathway contributes $16 \%$ of isoprene SOA, mostly from glyoxal. MEPOX contribution to isoprene SOA is small $(2 \%)$ and consistent with a recent laboratory study that finds low SOA yields from this pathway under humid conditions (Nguyen et al., 2015b). The minor low- $\mathrm{NO}_{x}$ pathways from $\mathrm{ISOPO}_{2}$ isomerization and reaction with $\mathrm{RO}_{2}$ contribute $8 \%$ of isoprene SOA through glyoxal. The remainder of isoprene SOA formation $(3 \%)$ is from nighttime oxidation by $\mathrm{NO}_{3}$.

The dominance of IEPOX and glyoxal as precursors for isoprene SOA was previously found by McNeill et al. (2012) using a photochemical box model. Both IEPOX and glyoxal are produced photochemically, and both are removed photochemically in the gas phase by reaction with $\mathrm{OH}$ (and photolysis for glyoxal). The mean lifetimes of IEPOX and glyoxal against gas-phase photochemical loss average 1.6 and $2.3 \mathrm{~h}$ respectively for $\mathrm{SEAC}{ }^{4} \mathrm{RS}$ daytime conditions; mean lifetimes against reactive uptake by aerosol are 31 and $20 \mathrm{~h}$, respectively. For both species, aerosol uptake is thus a minor sink competing with gas-phase photochemical loss. Although we have assumed here the fast gas-phase kinetics from Jacobs et al. (2013) for the IEPOX $+\mathrm{OH}$ reaction, this result would not change if we used the slower kinetics from Bates et al. (2014).

The dominance of gas-phase loss over aerosol uptake for both IEPOX and glyoxal implies that isoprene SOA formation is highly sensitive to their reactive uptake coefficients $\gamma$ and to the aqueous aerosol mass concentration (in both cases, $\gamma$ is small enough that uptake is controlled by bulk aqueous-phase rather than surface reactions). We find under SEAC ${ }^{4} \mathrm{RS}$ conditions that $\gamma$ for IEPOX is mainly controlled by the $\mathrm{H}^{+}$concentration $\left(k_{\mathrm{H}^{+}}\left[\mathrm{H}^{+}\right]\right.$in Eq. 2$)$, with little contribution from nucleophile-driven and $\mathrm{HSO}_{4}^{-}$-driven channels, although this is based on highly uncertain rate constants (Sect. 2). Consistency with SOAS and SEAC ${ }^{4} \mathrm{RS}$ observations will be discussed below.

The 3.3\% mean yield of isoprene SOA from our mechanism is consistent with the fixed yield of $3 \%$ assumed by Kim et al. (2015) in their GEOS-Chem simulation of the SEAC ${ }^{4} \mathrm{RS}$ period, including extensive comparisons to OA observations that showed a $40 \%$ mean contribution of isoprene to total OA. We conducted a sensitivity simulation using the default isoprene SOA mechanism in GEOS-Chem based on reversible partitioning of semivolatile oxidation products onto pre-existing OA (Pye et al., 2010). The iso- 

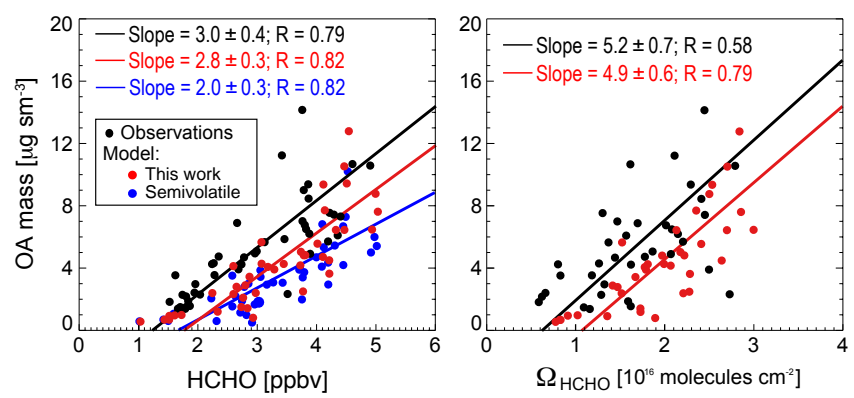

Figure 3. Relationship of organic aerosol (OA) and formaldehyde (HCHO) concentrations over the southeast US in summer. The figure shows scatter plots of SEAC ${ }^{4} \mathrm{RS}$ aircraft observations of OA concentrations in the boundary layer $(<2 \mathrm{~km})$ vs. HCHO mixing ratios measured from the aircraft (left), and column $\mathrm{HCHO}$ $\left(\Omega_{\mathrm{HCHO}}\right)$ retrieved from OMI satellite observations (right). Individual points denote data from individual SEAC ${ }^{4} \mathrm{RS}$ flight days (8 August-10 September), averaged on the GEOS-Chem grid. OMI data are for SEAC ${ }^{4} \mathrm{RS}$ flight days and coincident with the flight tracks. GEOS-Chem is sampled for the corresponding locations and times. Results from our simulation with aqueous-phase isoprene SOA chemistry are shown in red, and results from a simulation with the Pye et al. (2010) semivolatile reversible partitioning scheme are shown in blue. Aerosol concentrations are per $\mathrm{m}^{3}$ at standard conditions of temperature and pressure $(273 \mathrm{~K} ; 1 \mathrm{~atm})$, denoted $\mathrm{sm}^{-3}$. Reduced major axis (RMA) regressions are also shown with regression parameters and Pearson's correlation coefficients given inset. $1 \sigma$ standard deviations on the regression slopes are obtained with jackknife resampling.

prene SOA yield in that simulation was only $1.1 \%$. The observed correlation of OA with $\mathrm{HCHO}$ in SEAC ${ }^{4} \mathrm{RS}$ supports our higher yield, as shown below.

\section{Observational constraints on isoprene SOA yields}

Isoprene is the largest source of HCHO in the southeast US (Millet et al., 2006), and we use the observed relationship between OA and HCHO to evaluate the GEOS-Chem isoprene SOA yields. The SEAC ${ }^{4} \mathrm{RS}$ aircraft payload included measurements of OA from an Aerodyne High-Resolution Timeof-Flight Aerosol Mass Spectrometer (HR-ToF-AMS; DeCarlo et al., 2006; Canagaratna et al., 2007) concurrent with HCHO from a laser-induced fluorescence instrument (ISAF; Cazorla et al., 2015). Column HCHO was also measured during SEAC ${ }^{4} \mathrm{RS}$ from the Ozone Monitoring Instrument (OMI) satellite instrument (González Abad et al., 2015; Zhu et al., 2016), providing a proxy for isoprene emission (Palmer et al., 2003, 2006).

Figure 3 (left) shows the observed and simulated relationships between $\mathrm{OA}$ and $\mathrm{HCHO}$ mixing ratios in the boundary layer. There is a strong correlation in the observations and in the model ( $R=0.79$ and $R=0.82$, respectively). OA simulated with our aqueous-phase isoprene SOA mechanism reproduces the observed slope $\left(2.8 \pm 0.3 \mu \mathrm{g} \mathrm{sm}^{-3} \mathrm{ppbv}^{-1}\right.$,

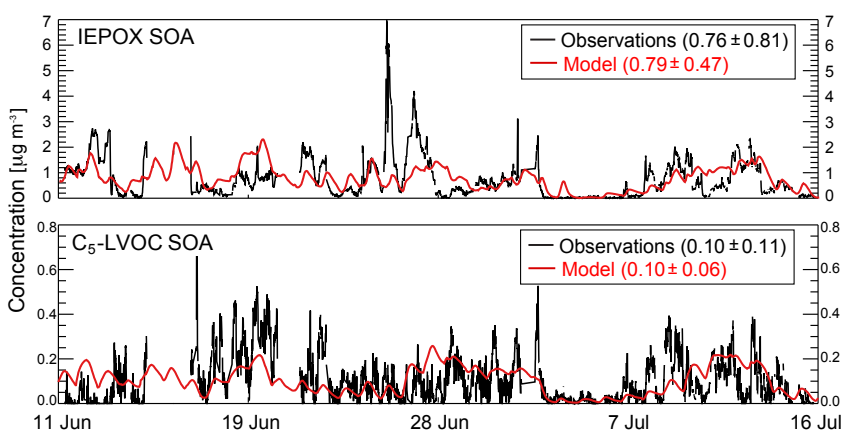

Figure 4. Time series of the concentrations of isoprene SOA components at the SOAS site in Centreville, Alabama $\left(32.94^{\circ} \mathrm{N}\right.$; $87.18^{\circ} \mathrm{W}$ ), in June-July 2013: measured (black) and modeled (red) IEPOX SOA (top) and $\mathrm{C}_{5}$-LVOC SOA (bottom) mass concentrations. Means and $1 \sigma$ standard deviations are given for the observations and the model.

vs. $3.0 \pm 0.4 \mu \mathrm{g} \mathrm{sm}^{-3} \mathrm{ppbv}^{-1}$ in the observations). Similarly strong correlations and consistency between model and observations are found with column $\mathrm{HCHO}$ measured from OMI (Fig. 3, right). The estimated error on individual OMI $\mathrm{HCHO}$ observations is about $30 \%$ (Millet et al., 2006).

Also shown in Fig. 3 is a sensitivity simulation with the default GEOS-Chem mechanism based on reversible partitioning with pre-existing organic aerosol (Pye et al., 2010) and producing a $1.1 \%$ mean isoprene SOA yield, as compared to $3.3 \%$ in our simulation with the aqueous-phase mechanism. That sensitivity simulation shows the same OAHCHO correlation $(R=0.82)$ but underestimates the slope $\left(2.0 \pm 0.3 \mu \mathrm{g} \mathrm{sm}^{-3} \mathrm{ppbv}^{-1}\right)$. The factor of 3 increase in our isoprene SOA yield does not induce a proportional increase in the slope, as isoprene contributes only $\sim 40 \%$ of OA in the southeast US. But the slope is sensitive to the isoprene SOA yield, and the good agreement between our simulation and observations supports our estimate of a mean $3.3 \%$ yield for the southeast US.

Figure 3 shows an offset between the model and observations illustrated by the regression lines. We overestimate $\mathrm{HCHO}$ by $0.4 \mathrm{ppbv}$ on average because we did not apply the $15 \%$ downward correction to MEGAN v2.1 isoprene emissions (Zhu et al., 2016). We also underestimate total OA measured by the AMS in the boundary layer by $1.1 \mu \mathrm{g} \mathrm{sm}^{-3}$ (mean AMS OA is $5.8 \pm 4.3 \mu \mathrm{g} \mathrm{sm}^{-3}$; model $\mathrm{OA}$ is $4.7 \pm 4.4 \mu \mathrm{g} \mathrm{sm}^{-3}$ ). The bias can be explained by our omission of anthropogenic and open fire SOA, found by Kim et al. (2015) to account on average for $18 \%$ of OA in SEAC ${ }^{4}$ RS.

Figure 4 shows time series of the isoprene SOA components IEPOX SOA and $\mathrm{C}_{5}$-LVOC SOA at Centreville, Alabama, during SOAS. AMS observations from $\mathrm{Hu}$ et al. (2015) and Krechmer et al. (2015) are compared to model values. IEPOX SOA and $\mathrm{C}_{5}$-LVOC SOA are on average 17 and $2 \%$ of total AMS OA, respectively (Hu et al., 2015; 


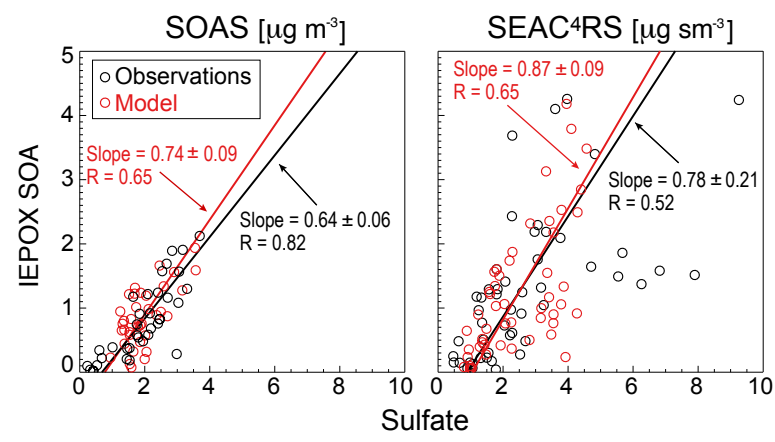

Figure 5. Relationship of IEPOX SOA and sulfate concentrations over the southeast US in summer. Observed (black) and simulated (red) data are averages for each campaign day during SOAS (left), and boundary-layer averages $(<2 \mathrm{~km})$ for $2^{\circ} \times 2.5^{\circ}$ GEOS-Chem grid squares on individual flight days during $\mathrm{SEAC}^{4} \mathrm{RS}$ (right). RMA regression slopes and Pearson's correlation coefficients are shown. $1 \sigma$ standard deviations on the regression slopes are obtained with jackknife resampling.

Krechmer et al., 2015). The model reproduces mean IEPOX SOA and $\mathrm{C}_{5}$-LVOC SOA without bias, supporting the conclusion that IEPOX is the dominant contributor to isoprene SOA in the southeast US (Fig. 2).

Figure 5 shows the relationships of daily mean IEPOX SOA and sulfate concentrations at Centreville and in the SEAC ${ }^{4} \mathrm{RS}$ boundary layer. The same factor analysis method was used to derive IEPOX SOA in SEAC ${ }^{4} \mathrm{RS}$ as in SOAS; however, the uncertainty is larger for the aircraft observations due to the much wider range of conditions encountered. There is a strong correlation between IEPOX SOA and sulfate, both in observations and the model, with similar slopes. Correlation between IEPOX SOA and sulfate has similarly been observed at numerous southeast US monitoring sites (Budisulistiorini et al., 2013, 2015; Xu et al., 2015; Hu et al., 2015). Xu et al. (2015) concluded that IEPOX SOA may form by nucleophilic addition of sulfate (sulfate channels in Eq. 2) leading to organosulfates. However, we find in our model that the $\mathrm{H}^{+}$-catalyzed channel $\left(k_{\mathrm{H}^{+}}\left[\mathrm{H}^{+}\right]\right.$ term in Eq. 2) contributes $90 \%$ of IEPOX SOA formation throughout the southeast US boundary layer, and that sulfate channels play only a minor role. The correlation of IEPOX SOA and sulfate in the model is because increasing sulfate drives an increase in aqueous aerosol volume and acidity. Although dominance of the $\mathrm{H}^{+}$-catalyzed channel is sensitive to uncertainties in the rate constants (Sect. 2), measurements from the PALMS (Particle Analysis by Laser Mass Spectrometry) instrument during SEAC ${ }^{4} \mathrm{RS}$ (Liao et al., 2015) show a mean IEPOX organosulfate concentration of $0.13 \mu \mathrm{g} \mathrm{sm}^{-3}$, amounting to at most $9 \%$ of total IEPOX SOA. The organosulfate should be a marker of the sulfate channels because its hydrolysis is negligibly slow (Hu et al., 2011).
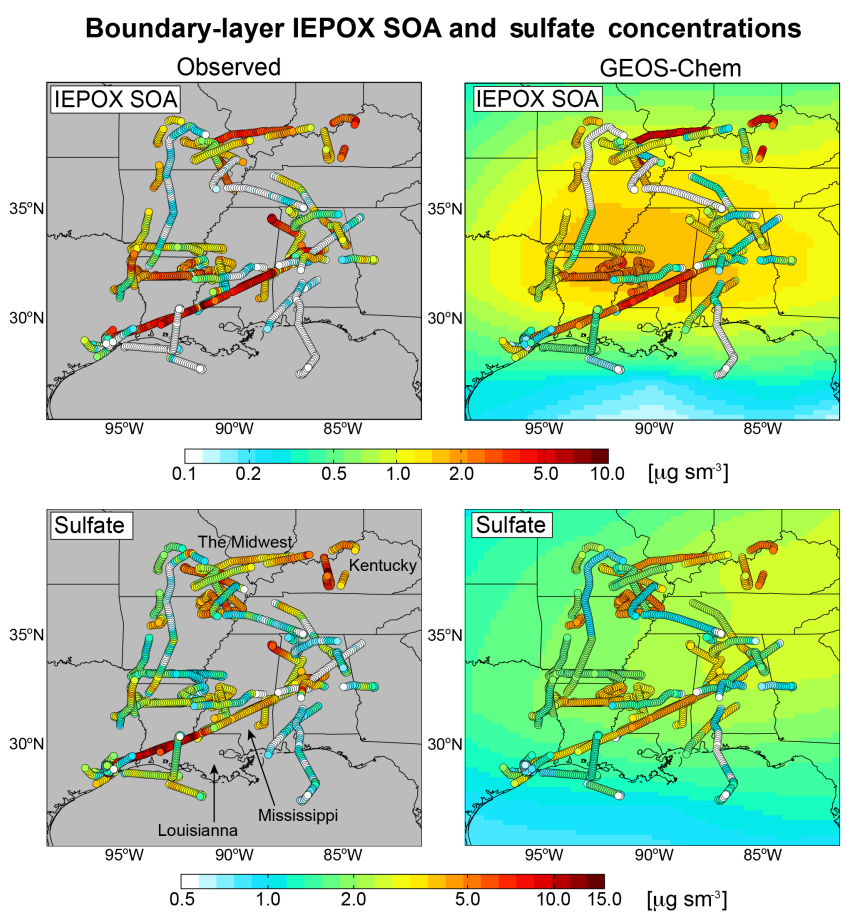

Figure 6. Spatial distributions of IEPOX SOA and sulfate concentrations in the boundary layer $(<2 \mathrm{~km})$ over the southeast US during SEAC ${ }^{4}$ RS (August-September 2013). Aircraft AMS observations of IEPOX SOA (top left) and sulfate (bottom left) are compared to model values sampled at the time and location of the aircraft observations (individual points) and averaged during the SEAC ${ }^{4} \mathrm{RS}$ period (background contours). Data are on a logarithmic scale.

Correlation between IEPOX SOA and sulfate is also apparent in the spatial distribution of IEPOX SOA, as observed by the SEAC ${ }^{4} \mathrm{RS}$ aircraft below $2 \mathrm{~km}$ and simulated by GEOS-Chem along the aircraft flight tracks (Fig. 6). The correlation between simulated and observed IEPOX SOA in Fig. 6 is $R=0.70$. Average (mean) IEPOX SOA is $1.4 \pm 1.4 \mu \mathrm{g} \mathrm{sm}^{-3}$ in the observations and $1.3 \pm 1.2 \mu \mathrm{g} \mathrm{sm}^{-3}$ in the model. The correlation between IEPOX SOA and sulfate is 0.66 in the observations and 0.77 in the model. IEPOX SOA concentrations are highest in the industrial Midwest and Kentucky, and in Louisiana-Mississippi, coincident with the highest sulfate concentrations sampled on the flights. We also see in Fig. 6 frequent observations of very low IEPOX SOA (less than $0.4 \mu \mathrm{g} \mathrm{sm}^{-3}$ ) that are well captured by the model. These are associated with very low sulfate (less than $\left.1 \mu \mathrm{g} \mathrm{sm}{ }^{-3}\right)$.

The mean IEPOX SOA concentration simulated by the model for the SEAC ${ }^{4} \mathrm{RS}$ period (background contours in Fig. 6) is far more uniform than IEPOX SOA simulated along the flight tracks. This shows the importance of dayto-day variations in sulfate in driving IEPOX SOA variability. IEPOX SOA contributed on average $24 \%$ of total OA in the SEAC ${ }^{4} \mathrm{RS}$ observations, and $28 \%$ in GEOS-Chem sampled along the flight tracks and as a regional mean. With 


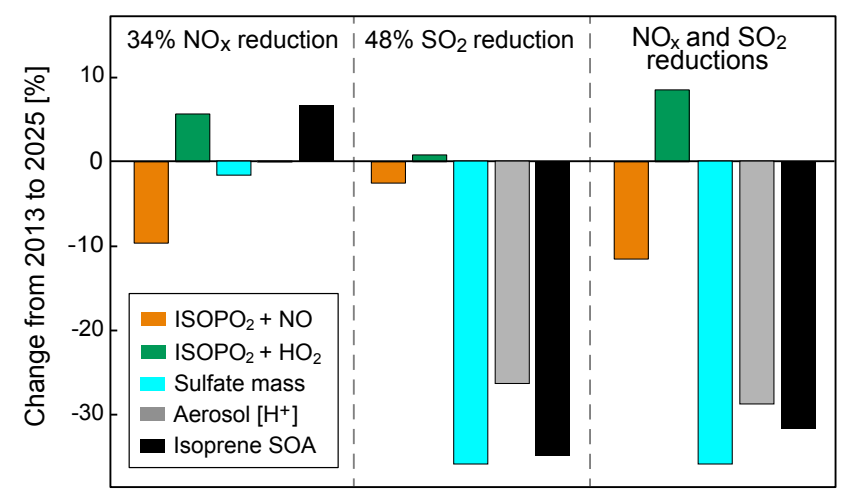

Figure 7. Effect of projected 2013-2025 reductions in US anthropogenic emissions on the formation of isoprene secondary organic aerosol (SOA). Emissions of $\mathrm{NO}_{x}$ and $\mathrm{SO}_{2}$ are projected to decrease by 34 and $48 \%$, respectively. Panels show the resulting percentage changes in the branching of $\mathrm{ISOPO}_{2}$ between the $\mathrm{NO}$ and $\mathrm{HO}_{2}$ oxidation channels, sulfate mass concentration, aerosol $\left[\mathrm{H}^{+}\right]$ concentration, and isoprene SOA mass concentration. Values are summer means for the southeast US boundary layer.

IEPOX SOA accounting for $58 \%$ of isoprene SOA in the model (Fig. 2), this amounts to a $41-48 \%$ contribution of isoprene to total OA, consistent with the previous estimate of $40 \%$ by Kim et al. (2015).

\section{Effect of anthropogenic emission reductions}

The Environmental Protection Agency (EPA) projects that US anthropogenic emissions of $\mathrm{NO}_{x}$ and $\mathrm{SO}_{2}$ will decrease respectively by 34 and $48 \%$ from 2013 to 2025 (EPA, 2014). We conducted a GEOS-Chem sensitivity simulation to examine the effect of these changes on isoprene SOA, assuming no other changes and further assuming that the emission decreases are uniform across the US.

Figure 7 shows the individual and combined effects of $\mathrm{NO}_{x}$ and $\mathrm{SO}_{2}$ emission reductions on the branching pathways for isoprene oxidation, sulfate mass concentration, aerosol $\mathrm{pH}$, and isoprene SOA in the southeast US boundary layer in summer. Reducing $\mathrm{NO}_{x}$ emission by $34 \%$ decreases the mean NO concentration by only $23 \%$, in part because decreasing $\mathrm{OH}$ increases the $\mathrm{NO}_{x}$ lifetime and in part because decreasing ozone increases the $\mathrm{NO} / \mathrm{NO}_{2}$ ratio. There is no change in $\mathrm{HO}_{2}$. We find a $10 \%$ decrease in the high$\mathrm{NO}_{x}$ pathway and a $6 \%$ increase in the low- $\mathrm{NO}_{x}$ pathway involving $\mathrm{ISOPO}_{2}+\mathrm{HO}_{2}$. Aerosol sulfate decreases by $2 \%$ and there is no change in $\left[\mathrm{H}^{+}\right]$. The net effect is a $7 \%$ increase in isoprene SOA, as the major individual components IEPOX SOA and glyoxal SOA increase by $17 \%$ and decrease by $8 \%$, respectively.

A $48 \%$ decrease in $\mathrm{SO}_{2}$ emissions drives a $36 \%$ reduction in sulfate mass concentration, leading to a decline in aerosol volume $(31 \%)$ that reduces uptake of all isoprene
SOA precursors. The decrease in aerosol $\left[\mathrm{H}^{+}\right](26 \%)$ further reduces IEPOX uptake. Decline in aerosol volume and $\left[\mathrm{H}^{+}\right]$ have a comparable effect on IEPOX SOA, as the change in each due to $\mathrm{SO}_{2}$ emission reductions is similar $(\sim 30 \%)$ and uptake of IEPOX SOA is proportional to the product of the two (Sect. 4). IEPOX SOA and glyoxal SOA decrease by 45 and $26 \%$, respectively, and total isoprene SOA decreases by $35 \%$. Pye et al. (2013) included uptake of IEPOX to aqueous aerosols in a regional chemical transport model and similarly found that $\mathrm{SO}_{2}$ emissions are more effective than $\mathrm{NO}_{x}$ emissions at reducing IEPOX SOA in the southeast US. Remarkably, we find that reducing $\mathrm{SO}_{2}$ emissions decreases sulfate and isoprene SOA with similar effectiveness (Fig. 7). With sulfate contributing $\sim 30 \%$ of present-day $\mathrm{PM}_{2.5}$ in the southeast US and isoprene SOA contributing $\sim 25 \%$ (Kim et al., 2015), this represents a factor of 2 co-benefit on $\mathrm{PM}_{2.5}$ from reducing $\mathrm{SO}_{2}$ emissions.

\section{Conclusions}

Standard mechanisms for the formation of isoprene secondary organic aerosol (SOA) in chemical transport models assume reversible partitioning of isoprene oxidation products to pre-existing dry OA. This may be appropriate for dry conditions in experimental chambers but not for typical atmospheric conditions where the aerosol is mostly aqueous. Here we developed an aqueous-phase reactive uptake mechanism coupled to a detailed gas-phase isoprene chemistry mechanism to describe the reactive uptake of water-soluble isoprene oxidation products to aqueous aerosol. We applied this mechanism in the GEOS-Chem chemical transport model to simulate surface (SOAS) and aircraft (SEAC $\left.{ }^{4} \mathrm{RS}\right)$ observations over the southeast US in summer 2013.

Our mechanism includes different channels for isoprene SOA formation by the high- $\mathrm{NO}_{x}$ pathway, when the isoprene peroxy radicals $\left(\mathrm{ISOPO}_{2}\right)$ react with $\mathrm{NO}$, and in the low$\mathrm{NO}_{x}$ pathway where they react mostly with $\mathrm{HO}_{2}$. The main SOA precursors are found to be isoprene epoxide (IEPOX) in the low- $\mathrm{NO}_{x}$ pathway and glyoxal in the high- and low- $\mathrm{NO}_{x}$ pathways. Both of these precursors have dominant gas-phase photochemical sinks, and so their uptake by aqueous aerosol is nearly proportional to the reactive uptake coefficient $\gamma$ and to the aqueous aerosol mass concentration. The $\gamma$ for IEPOX is mostly determined by the rate of $\mathrm{H}^{+}$-catalyzed ring opening in the aqueous phase.

Application of our mechanism to the southeast US indicates a mean isoprene SOA yield of $3.3 \%$ on a mass basis. By contrast, a conventional mechanism based on reversible uptake of semivolatile isoprene oxidation products yields only $1.1 \%$. Simulation of the observed relationship of OA with formaldehyde (HCHO) provides support for our higher yield. We find that the low- $\mathrm{NO}_{x}$ pathway is 5 times more efficient than the high- $\mathrm{NO}_{x}$ pathway for isoprene SOA pro- 
duction. Under southeast US conditions, IEPOX and glyoxal account respectively for 58 and $28 \%$ of isoprene SOA.

Our model simulates the observations and variability of IEPOX SOA at the surface and from aircraft well. The observations show a strong correlation with sulfate that we reproduce in the model. We find this is due to the effect of sulfate on aerosol $\mathrm{pH}$ and volume concentration, increasing IEPOX uptake by the $\mathrm{H}^{+}$-catalyzed ring-opening mechanism. Low concentrations of sulfate are associated with very low IEPOX SOA, both in the observations and the model, and we attribute this to the compounding effects of low sulfate on aerosol $\left[\mathrm{H}^{+}\right]$and on aerosol volume.

The US EPA has projected that US $\mathrm{NO}_{x}$ and $\mathrm{SO}_{2}$ emissions will decrease by 34 and $48 \%$ respectively from 2013 to 2025 . We find in our model that the $\mathrm{NO}_{x}$ reduction will increase isoprene SOA by $7 \%$, reflecting greater importance of the low- $\mathrm{NO}_{x}$ pathway. The $\mathrm{SO}_{2}$ reduction will decrease isoprene SOA by $35 \%$, due to decreases in both aerosol $\left[\mathrm{H}^{+}\right]$ and volume concentration. The combined effect of these two changes is to decrease isoprene SOA by $32 \%$, corresponding to a decrease in the isoprene SOA mass yield from 3.3 to $2.3 \%$. Decreasing $\mathrm{SO}_{2}$ emissions by $48 \%$ has similar relative effects on sulfate (36\%) and isoprene SOA (35\%). Considering that sulfate presently accounts for about $30 \%$ of $\mathrm{PM}_{2.5}$ in the southeast US in summer, while isoprene SOA contributes $25 \%$, we conclude that decreasing isoprene SOA represents a factor of 2 co-benefit when reducing $\mathrm{SO}_{2}$ emissions.

Acknowledgements. We are grateful to the entire NASA SEAC ${ }^{4} \mathrm{RS}$ team for their help in the field, in particular Paul Wennberg, John Crounse, Jason St. Clair, and Alex Teng for their CIT-CIMS measurements. Thanks also to Jesse Kroll for assisting in the interpretation of chamber study results. This work was funded by the NASA Tropospheric Chemistry Program, the NASA Air Quality Applied Sciences Team, and a South African National Research Foundation Fellowship and Schlumberger Faculty for the Future Fellowship to E. A. Marais. W. Hu, J. Krechmer, P. Campuzano-Jost, D. A. Day, and J. L. Jimenez were supported by NASA NNX12AC03G/NNX15AT96G and NSF AGS-1243354. J. Krechmer was supported by EPA STAR (FP-91770901-0) and CIRES Fellowships. J. A. Fisher acknowledges support from a University of Wollongong Vice Chancellor's Postdoctoral Fellowship. HCHO observations were acquired with support from NASA ROSES SEAC ${ }^{4}$ RS grant NNH10ZDA001N. Although this document has been reviewed by US EPA and approved for publication, it does not necessarily reflect US EPA's policies or views.

Edited by: F. Yu

\section{References}

Anttila, T., Kiendler-Scharr, A., Tillmann, R., and Mentel, T. F.: On the reactive uptake of gaseous compounds by organic-coated aqueous aerosols: Theoretical analysis and application to the heterogeneous hydrolysis of $\mathrm{N}_{2} \mathrm{O}_{5}$, J. Phys. Chem. A, 110, 1043510443, doi:10.1021/jp062403c, 2006.

Attwood, A. R., Washenfelder, R. A., Brock, C. A., Hu, W., Baumann, K., Campuzano-Jost, P., Day, D. A., Edgerton, E. S., Murphy, D. M., Palm, B. B., McComiskey, A., Wagner, N. L., de Sá, S. S., Ortega, A., Martin, S. T., Jimenez, J. L., and Brown, S. S.: Trends in sulfate and organic aerosol mass in the Southeast U.S.: Impact on aerosol optical depth and radiative forcing, Geophys. Res. Lett., 41, 7701-7709, doi:10.1002/2014gl061669, 2014.

Bateman, A. P., Bertram, A. K., and Martin, S. T.: Hygroscopic influence on the semisolid-to-liquid transition of secondary organic materials, J. Phys. Chem. A., 119, 4386-4395, doi:10.1021/jp508521c, 2014.

Bates, K. H., Crounse, J. D., St Clair, J. M., Bennett, N. B., Nguyen, T. B., Seinfeld, J. H., Stoltz, B. M., and Wennberg, P. O.: Gas phase production and loss of isoprene epoxydiols, J. Phys. Chem. A, 118, 1237-1246, doi:10.1021/jp4107958, 2014.

Brégonzio-Rozier, L., Giorio, C., Siekmann, F., Pangui, E., Morales, S. B., Temime-Roussel, B., Gratien, A., Michoud, V., Cazaunau, M., DeWitt, H. L., Tapparo, A., Monod, A., and Doussin, J.-F.: Secondary Organic Aerosol formation from isoprene photooxidation during cloud condensationevaporation cycles, Atmos. Chem. Phys. Discuss., 15, 2056120596, doi:10.5194/acpd-15-20561-2015, 2015.

Brown, S. S., deGouw, J. A., Warneke, C., Ryerson, T. B., Dubé, W. P., Atlas, E., Weber, R. J., Peltier, R. E., Neuman, J. A., Roberts, J. M., Swanson, A., Flocke, F., McKeen, S. A., Brioude, J., Sommariva, R., Trainer, M., Fehsenfeld, F. C., and Ravishankara, A. R.: Nocturnal isoprene oxidation over the Northeast United States in summer and its impact on reactive nitrogen partitioning and secondary organic aerosol, Atmos. Chem. Phys., 9, 30273042, doi:10.5194/acp-9-3027-2009, 2009.

Budisulistiorini, S. H., Canagaratna, M. R., Croteau, P. L., Marth, W. J., Baumann, K., Edgerton, E. S., Shaw, S. L., Knipping, E. M., Worsnop, D. R., Jayne, J. T., Gold, A., and Surratt, J. D.: Real-time continuous characterization of secondary organic aerosol derived from isoprene epoxydiols in downtown Atlanta, Georgia, using the Aerodyne aerosol chemical speciation monitor, Environ. Sci. Technol., 47, 5686-5694, doi:10.1021/es400023n, 2013.

Budisulistiorini, S. H., Li, X., Bairai, S. T., Renfro, J., Liu, Y., Liu, Y. J., McKinney, K. A., Martin, S. T., McNeill, V. F., Pye, H. O. T., Nenes. A., Neff, M. E., Stone, E. A., Mueller, S., Knote, C., Shaw, S. L., Zhang, Z., Gold, A., and Surratt, J. D.: Examining the effects of anthropogenic emissions on isoprenederived secondary organic aerosol formation during the 2013 Southern Oxidant and Aerosol Study (SOAS) at the Look Rock, Tennessee ground site, Atmos. Chem. Phys., 15, 8871-8888, doi:10.5194/acp-15-8871-2015, 2015.

Buxton, G. V., Malone, T. N., and Salmon, G. A.: Oxidation of glyoxal initiated by $\cdot \mathrm{OH}$ in oxygenated aqueous solution, J. Chem. Soc. Faraday T., 93, 2889-2891, doi:10.1039/A701468f, 1997.

Canagaratna, M. R., Jayne, J. T., Jimenez, J. L., Allan, J. D., Alfarra, M. R, Zhang, Q., Onasch, T. B., Drewnick, F., Coe, H., Middlebrook, A., Delia, A., Williams, L. R., Trimborn, A. M., 
Northway, M. J., DeCarlo, P. F., Kolb, C. E., Davidovits, P., and Worsnop, D. R.: Chemical and microphysical characterization of ambient aerosols with the Aerodyne Aerosol Mass Spectrometer, Mass Spectrom. Rev., 26, 185-222, doi:10.1002/mas.20115, 2007.

Carlton, A. G., Turpin, B. J., Altieri, K. E., Seitzinger, S. P., Mathur, R., Roselle, S. J., and Weber, R. J.: CMAQ model performance enhanced when in-cloud secondary organic aerosol is included: Comparisons of organic carbon predictions with measurements, Environ. Sci. Technol., 42, 8789-8802, doi:1021/es801192n, 2008.

Carlton, A. G., Wiedinmyer, C., and Kroll, J. H.: A review of Secondary Organic Aerosol (SOA) formation from isoprene, Atmos. Chem. Phys., 9, 4987-5005, doi:10.5194/acp-9-4987-2009, 2009.

Carlton, A. G. and Turpin, B. J.: Particle partitioning potential of organic compounds is highest in the Eastern US and driven by anthropogenic water, Atmos. Chem. Phys., 13, 10203-10214, doi:10.5194/acp-13-10203-2013, 2013.

Cazorla, M., Wolfe, G. M., Bailey, S. A., Swanson, A. K., Arkinson, H. L., and Hanisco, T. F.: A new airborne laser-induced fluorescence instrument for in situ detection of formaldehyde throughout the troposphere and lower stratosphere, Atmos. Meas. Tech., 8, 541-552, doi:10.5194/amt-8-541-2015, 2015.

Chan, A. W. H., Chan, M. N., Surratt, J. D., Chhabra, P. S., Loza, C. L., Crounse, J. D., Yee, L. D., Flagan, R. C., Wennberg, P. O., and Seinfeld, J. H.: Role of aldehyde chemistry and $\mathrm{NO}_{x}$ concentrations in secondary organic aerosol formation, Atmos. Chem. Phys., 10, 7169-7188, doi:10.5194/acp-10-7169-2010, 2010.

Cole-Filipiak, N. C., O'Connor, A. E., and Elrod, M. J.: Kinetics of the hydrolysis of atmospherically relevant isoprenederived hydroxy epoxides, Environ. Sci. Technol., 44, 67186723, doi:10.1021/es1019228, 2010.

Darer, A. I., Cole-Filipiak, N. C., O'Connor, A. E., and Elrod, M. J.: Formation and stability of atmospherically relevant isoprenederived organosulfates and organonitrates, Environ. Sci. Technol., 45, 1895-1902, doi:10.1021/es103797z, 2011.

DeCarlo, P. F., Kimmel, J. R. Trimborn, A., Northway, M. J., Jayne, J. T., Aiken, A. C., Gonin, M., Fuhrer, K., Horvath, T., Docherty, K. S., Worsnop, D. R., and Jimenez, J. L.: Field-deployable, High-Resolution, Time-of-Flight Aerosol Mass Spectrometer, Anal. Chem., 78, 8281-8289, doi:10.1021/ac061249n, 2006.

Dommen, J., Metzger, A., Duplissy, J., Kalberer, M., Alfarra, M. R., Gascho, A., Weingartner, E., Prévôt, A. S. H., Verheggen, B., and Baltensperger, U.: Laboratory observation of oligomers in the aerosol from isoprene/ $\mathrm{NO}_{x}$ photooxidation, Geophys. Res. Lett., 33, L13805, doi:10.1029/2006gl026523, 2006.

Donahue, N. M., Robinson, A. L., Stanier, C. O., and Pandis, S. N.: Coupled partitioning, dilution, and chemical aging of semivolatile organics, Environ. Sci. Technol., 40, 2635-2643, doi:10.1021/es052297c, 2006.

Drury, E., Jacob, D. J., Spurr, R. J. D., Wang, J., Shinozuka, Y., Anderson, B. E., Clarke, A. D., Dibb, J., McNaughton, C., and Weber, R.: Synthesis of satellite (MODIS), aircraft (ICARTT), and surface (IMPROVE, EPA-AQS, AERONET) aerosol observations over eastern North America to improve MODIS aerosol retrievals and constrain surface aerosol concentrations and sources, J. Geophys. Res., 115, D14204, doi:10.1029/2009jd012629, 2010 .
Eddingsaas, N. C., VanderVelde, D. G., and Wennberg, P. O.: Kinetics and products of the acid-catalyzed ring-opening of atmospherically relevant butyl epoxy alcohols, J. Phys. Chem. A, 114, 8106-8113, doi:10.1021/jp103907c, 2010.

Edney, E. O., Kleindienst, T. E., Jaoui, M., Lewandowski, M., Offenberg, J. H., Wang, W., and Claeys, M.: Formation of 2methyl tetrols and 2-methylglyceric acid in secondary organic aerosol from laboratory irradiated isoprene/ $/ \mathrm{NO}_{x} / \mathrm{SO}_{2} /$ air mixtures and their detection in ambient $\mathrm{PM}_{2.5}$ samples collected in the eastern United States, Atmos. Environ., 39, 5281-5289, doi:10.1016/j.atmosenv.2005.05.031, 2005.

EPA: U.S. Environmental Protection Agency, Technical Support Document (TSD): Preparation of Emissions Inventories for the Version 6.1, 2011 Emissions Modeling Platform, available at: http://www.epa.gov/ttn/chief/emch/2011v6/2011v6.1_ 2018_2025_base_EmisMod_TSD_nov2014_v6.pdf (last access: 15 July 2015), 2014.

Ervens, B., Gligorovski, S., and Herrmann, H.: Temperaturedependent rate constants for hydroxyl radical reactions with organic compounds in aqueous solutions, Phys. Chem. Chem. Phys., 5, 1811-1824, doi:10.1039/b300072a, 2003.

Ervens, B., Turpin, B. J., and Weber, R. J.: Secondary organic aerosol formation in cloud droplets and aqueous particles (aqSOA): a review of laboratory, field and model studies, Atmos. Chem. Phys., 11, 11069-11102, doi:10.5194/acp-1111069-2011, 2011.

Fisher, J. A., Jacob, D. J., Travis, K. R., Kim, P. S., Marais, E. A., Chan Miller, C., Yu, K., Zhu, L., Yantosca, R. M., Sulprizio, M. P., Mao, J., Wennberg, P. O., Crounse, J. D., Teng, A. P., Nguyen, T. B., St. Clair, J. M., Cohen, R. C., Romer, P., Nault, B. A., Wooldridge, P. J., Jimenez, J. L., Campuzano-Jost, P., Day, D. A., Shepson, P. B., Xiong, F., Blake, D. R., Goldstein, A. H., Misztal, P. K., Hanisco, T. F., Wolfe, G. M., Ryerson, T. B., Wisthaler, A., and Mikoviny, T.: Organic nitrate chemistry and its implications for nitrogen budgets in an isoprene- and monoterpene-rich atmosphere: constraints from aircraft $\left(\mathrm{SEAC}^{4} \mathrm{RS}\right)$ and ground-based (SOAS) observations in the Southeast US, Atmos. Chem. Phys. Discuss., doi:10.5194/acp-2016-52, in review, 2016.

Fountoukis, C. and Nenes, A.: ISORROPIA II: a computationally efficient thermodynamic equilibrium model for $\mathrm{K}^{+}$$\mathrm{Ca}^{2+}-\mathrm{Mg}^{2+}-\mathrm{NH}^{4+}-\mathrm{Na}^{+}-\mathrm{SO}_{4}^{2-}-\mathrm{NO}_{3}^{-} \mathrm{Cl}^{-}-\mathrm{H}_{2} \mathrm{O}$ aerosols, Atmos. Chem. Phys., 7, 4639-4659, doi:10.5194/acp-7-4639-2007, 2007.

Fu, T.-M., Jacob, D. J., Wittrock, F., Burrows, J. P., Vrekoussis, M., and Henze, D. K.: Global budgets of atmospheric glyoxal and methylglyoxal, and implications for formation of secondary organic aerosols, J. Geophys. Res., 113, D15303, doi:10.1029/2007jd009505, 2008.

Fu, T.-M., Jacob, D. J., and Heald, C. L.: Aqueous-phase reactive uptake of dicarbonyls as a source of organic aerosol over eastern North America, Atmos. Environ., 43, 1814-1822, doi:10.1016/j.atmosenv.2008.12.029, 2009.

Gaston, C. J., Riedel, T. P., Zhang, Z., Gold, A., Surratt, J. D., and Thornton, J. A.: Reactive uptake of an isoprene-derived epoxydiol to submicron aerosol particles, Environ. Sci. Technol., 48, 11178-11186, doi:10.1021/es5034266, 2014.

González Abad, G., Liu, X., Chance, K., Wang, H., Kurosu, T. P., and Suleiman, R.: Updated Smithsonian Astrophysical Observatory Ozone Monitoring Instrument (SAO OMI) formaldehyde 
retrieval, Atmos. Meas. Tech., 8, 19-32, doi:10.5194/amt-8-192015, 2015.

Guenther, A., Karl, T., Harley, P., Wiedinmyer, C., Palmer, P. I., and Geron, C.: Estimates of global terrestrial isoprene emissions using MEGAN (Model of Emissions of Gases and Aerosols from Nature), Atmos. Chem. Phys., 6, 3181-3210, doi:10.5194/acp-63181-2006, 2006.

Guenther, A. B., Jiang, X., Heald, C. L., Sakulyanontvittaya, T., Duhl, T., Emmons, L. K., and Wang, X.: The Model of Emissions of Gases and Aerosols from Nature version 2.1 (MEGAN2.1): an extended and updated framework for modeling biogenic emissions, Geosci. Model Dev., 5, 1471-1492, doi:10.5194/gmd-51471-2012, 2012.

Guo, H., Xu, L., Bougiatioti, A., Cerully, K. M., Capps, S. L., Hite Jr., J. R., Carlton, A. G., Lee, S.-H., Bergin, M. H., Ng, N. L., Nenes, A., and Weber, R. J.: Fine-particle water and $\mathrm{pH}$ in the southeastern United States, Atmos. Chem. Phys., 15, 5211-5228, doi:10.5194/acp-15-5211-2015, 2015.

Hallquist, M., Wenger, J. C., Baltensperger, U., Rudich, Y., Simpson, D., Claeys, M., Dommen, J., Donahue, N. M., George, C., Goldstein, A. H., Hamilton, J. F., Herrmann, H., Hoffmann, T., Iinuma, Y., Jang, M., Jenkin, M. E., Jimenez, J. L., Kiendler-Scharr, A., Maenhaut, W., McFiggans, G., Mentel, Th. F., Monod, A., Prévôt, A. S. H., Seinfeld, J. H., Surratt, J. D., Szmigielski, R., and Wildt, J.: The formation, properties and impact of secondary organic aerosol: current and emerging issues, Atmos. Chem. Phys., 9, 5155-5236, doi:10.5194/acp-9-51552009, 2009.

Hess, M., Koepke, P., and Schult, I.: Optical properties of aerosols and clouds: The software package OPAC, B. Am. Meteorol. Soc., 79, 831-844, 1998.

Hodzic, A. and Jimenez, J. L.: Modeling anthropogenically controlled secondary organic aerosols in a megacity: a simplified framework for global and climate models, Geosci. Model Dev., 4, 901-917, doi:10.5194/gmd-4-901-2011, 2011.

Hu, K. S., Darer, A. I., and Elrod, M. J.: Thermodynamics and kinetics of the hydrolysis of atmospherically relevant organonitrates and organosulfates, Atmos. Chem. Phys., 11, 8307-8320, doi:10.5194/acp-11-8307-2011, 2011

Hu, W. W., Campuzano-Jost, P., Palm, B. B., Day, D. A., Ortega, A. M., Hayes, P. L., Krechmer, J. E., Chen, Q., Kuwata, M., Liu, Y. J., de Sá, S. S., McKinney, K., Martin, S. T., Hu, M., Budisulistiorini, S. H., Riva, M., Surratt, J. D., St. Clair, J. M., Isaacman-Van Wertz, G., Yee, L. D., Goldstein, A. H., Carbone, S., Brito, J., Artaxo, P., de Gouw, J. A., Koss, A., Wisthaler, A., Mikoviny, T., Karl, T., Kaser, L., Jud, W., Hansel, A., Docherty, K. S., Alexander, M. L., Robinson, N. H., Coe, H., Allan, J. D., Canagaratna, M. R., Paulot, F., and Jimenez, J. L.: Characterization of a real-time tracer for isoprene epoxydiols-derived secondary organic aerosol (IEPOX-SOA) from aerosol mass spectrometer measurements, Atmos. Chem. Phys., 15, 11807-11833, doi:10.5194/acp-15-11807-2015, 2015.

Jacob, D. J.: Heterogeneous chemistry and tropospheric ozone, Atmos. Environ., 34, 2131-2159, doi:10.1016/s13522310(99)00462-8, 2000

Jacobs, M. I., Darer, A. I., and Elrod, M. J.: Rate constants and products of the $\mathrm{OH}$ reaction with isoprene-derived epoxides, Environ. Sci. Technol., 47, 12868-12876, doi:10.1021/es403340g, 2013.
Jacobs, M. I., Burke, W. J., and Elrod, M. J.: Kinetics of the reactions of isoprene-derived hydroxynitrates: gas phase epoxide formation and solution phase hydrolysis, Atmos. Chem. Phys., 14, 8933-8946, doi:10.5194/acp-14-8933-2014, 2014.

Kim, P. S., Jacob, D. J., Fisher, J. A., Travis, K., Yu, K., Zhu, L., Yantosca, R. M., Sulprizio, M. P., Jimenez, J. L., CampuzanoJost, P., Froyd, K. D., Liao, J., Hair, J. W., Fenn, M. A., Butler, C. F., Wagner, N. L., Gordon, T. D., Welti, A., Wennberg, P. O., Crounse, J. D., St. Clair, J. M., Teng, A. P., Millet, D. B., Schwarz, J. P., Markovic, M. Z., and Perring, A. E.: Sources, seasonality, and trends of southeast US aerosol: an integrated analysis of surface, aircraft, and satellite observations with the GEOS-Chem chemical transport model, Atmos. Chem. Phys., 15, 10411-10433, doi:10.5194/acp-15-10411-2015, 2015.

King, S. M., Rosenoern, T., Shilling, J. E., Chen, Q., Wang, Z., Biskos, G., McKinney, K. A., Pöschl, U., and Martin, S. T.: Cloud droplet activation of mixed organic-sulfate particles produced by the photooxidation of isoprene, Atmos. Chem. Phys., 10, 3953-3964, doi:10.5194/acp-10-3953-2010, 2010.

Kleindienst, T. E., Edney, E. O., Lewandowski, M., Offenberg, J. H., and Jaoui, M.: Secondary organic carbon and aerosol yields from the irradiations of isoprene and $\alpha$-pinene in the presence of $\mathrm{NO}_{x}$ and $\mathrm{SO}_{2}$, Environ. Sci. Technol., 40, 3807-3812, doi:10.1021/es052446r, 2006.

Kleindienst, T. E., Lewandowski, M., Offenberg, J. H., Jaoui, M., and Edney, E. O.: Ozone-isoprene reaction: Re-examination of the formation of secondary organic aerosol, Geophys. Res. Lett., 34, L01805, doi:10.1029/2006g1027485, 2007.

Kleindienst, T. E., Lewandowski, M., Offenberg, J. H., Jaoui, M., and Edney, E. O.: The formation of secondary organic aerosol from the isoprene $+\mathrm{OH}$ reaction in the absence of $\mathrm{NO}_{x}$, Atmos. Chem. Phys., 9, 6541-6558, doi:10.5194/acp-9-6541-2009, 2009.

Knote, C., Hodzic, A., Jimenez, J. L., Volkamer, R., Orlando, J. J., Baidar, S., Brioude, J., Fast, J., Gentner, D. R., Goldstein, A. H., Hayes, P. L., Knighton, W. B., Oetjen, H., Setyan, A., Stark, H., Thalman, R., Tyndall, G., Washenfelder, R., Waxman, E., and Zhang, Q.: Simulation of semi-explicit mechanisms of SOA formation from glyoxal in aerosol in a 3-D model, Atmos. Chem. Phys., 14, 6213-6239, doi:10.5194/acp-14-6213-2014, 2014.

Koepke, P., Hess, M., Schult, I., and Shettle, E. P.: Global aerosol data set, report, Max-Planck Inst. für Meteorol., Hamburg, Germany, 1997.

Krechmer, J. E., Coggon, M. M., Massoli, P., Nguyen, T. B., Crounse, J. D., Hu, W., Day, D. A., Tyndall, G. S., Henze, D. K., Rivera-Rios, J. C., Nowak, J. B., Kimmel, J. R., Mauldin, III, R. L., Stark, H., Jayne, J. T., Sipilä, M., Junninen, H., St. Clair, J. M., Zhang, X., Feiner, P. A., Zhang, L., Miller, D. O., Brune, W. H., Keutsch, F. N., Wennberg, P. O., Seinfeld, J. H., Worsnop, D. R., Jimenez, J. L., and Canagaratna, M. R.: Formation of low volatility organic compounds and secondary organic aerosol from isoprene hydroxyhydroperoxide low-NO oxidation, Environ. Sci. Technol., 49, 10330-10339, doi:10.1021/acs.est.5b02031, 2015.

Kroll, J. H., Ng, N. L., Murphy, S. M., Flagan, R. C., and Seinfeld, J. H.: Secondary organic aerosol formation from isoprene photooxidation under high- $\mathrm{NO}_{x}$ conditions, Geophys. Res. Lett., 32, L18808, doi:10.1029/2005g1023637, 2005.

Kroll, J. H., Ng, N. L., Murphy, S. M., Flagan, R. C., and Seinfeld, J. H.: Secondary organic aerosol formation from iso- 
prene photooxidation, Environ. Sci. Technol., 40, 1869-1877, doi:10.1021/es0524301, 2006.

Lee, L., Teng, A. P., Wennberg, P. O., Crounse, J. D., and Cohen, R. C.: On rates and mechanisms of $\mathrm{OH}$ and $\mathrm{O}_{3}$ reactions with isoprene-derived hydroxy nitrates, J. Phys. Chem. A, 118, 16221637, doi:10.1021/jp4107603, 2014.

Lewandowski, M., Jaoui, M., Offenberg, J. H., Krug, J. D., and Kleindienst, T. E.: Atmospheric oxidation of isoprene and 1,3butadiene: influence of aerosol acidity and relative humidity on secondary organic aerosol, Atmos. Chem. Phys., 15, 3773-3783, doi:10.5194/acp-15-3773-2015, 2015.

Liao, J., Froyd, K. D., Murphy, D. M., Keutsch, F. N., Yu, G., Wennberg, P. O., St Clair, J. M., Crounse, J. D., Wisthaler, A., Mikoviny, T., Jimenez, J. L., Campuzano-Jost, P., Day, D. A., Hu, W., Ryerson, T. B., Pollack, I. B., Peischl, J., Anderson, B. E., Ziemba, L. D., Blake, D. R., Meinardi, S., and Diskin, G.: Airborne measurements of organosulfates over the continental U.S., J. Geophys. Res., 120, 2990-3005, doi:10.1002/2014jd022378, 2015.

Liggio, J., Li, S.-M., and McLaren, R.: Reactive uptake of glyoxal by particulate matter, J. Geophys. Res., 110, D10304, doi:10.1029/2004jd005113, 2005.

Lin, Y.-H., Zhang, H., Pye, H. O. T., Zhang, Z. F., Marth, W. J., Park, S., Arashiro, M., Cui, T., Budisulistiorini, S. H., Sexton, K. G., Vizuete, W., Xie, Y., Luecken, D. J., Piletic, I. R., Edney, E. O., Bartolotti, L. J., Gold, A., and Surratt, J. D.: Epoxide as a precursor to secondary organic aerosol formation from isoprene photooxidation in the presence of nitrogen oxides, P. Natl. Acad. Sci. USA, 110, 6718-6723, doi:10.1073/pnas.1221150110, 2013.

Lin, G., Sillman, S., Penner, J. E., and Ito, A.: Global modeling of SOA: the use of different mechanisms for aqueous-phase formation, Atmos. Chem. Phys., 14, 5451-5475, doi:10.5194/acp-145451-2014, 2014.

Liu, J., Horowitz, L. W., Fan, S., Carlton, A. G., and Levy II, H.: Global in-cloud production of secondary organic aerosols: implementation of a detailed chemical mechanism in the GFDL atmospheric model AM3, J. Geosphys. Res., 117, D15303, doi:10.1029/2012JD017838, 2012.

Liu, Y. J., Herdlinger-Blatt, I., McKinney, K. A., and Martin, S. T.: Production of methyl vinyl ketone and methacrolein via the hydroperoxyl pathway of isoprene oxidation, Atmos. Chem. Phys., 13, 5715-5730, doi:10.5194/acp-13-5715-2013, 2013.

Mao, J., Paulot, F., Jacob, D. J., Cohen, R. C., Crounse, J. D., Wennberg, P. O., Keller, C. A., Hudman, R. C., Barkley, M. P., and Horowitz, L. W.: Ozone and organic nitrates over the eastern United States: Sensitivity to isoprene chemistry, J. Geophys. Res., 118, 11256-11268, doi:10.1002/jgrd.50817, 2013.

Martin, R. V., Jacob, D. J., Yantosca, R. M., Chin, M., and Ginoux, P.: Global and regional decreases in tropospheric oxidants from photochemical effects of aerosols, J. Geophys. Res., 108, 4097, doi:10.1029/2002jd002622, 2003.

McNeill, V. F., Woo, J. L., Kim, D. D., Schwier, A. N., Wannell, N. J., Sumner, A. J., and Barakat, J. M.: Aqueous-phase secondary organic aerosol and organosulfate formation in atmospheric aerosols: A modeling study, Environ. Sci. Technol., 46, 8075-8081, doi:10.1021/es3002986, 2012.

McNeill, V. F., Sareen, N., and Schwier, A. N.: Surface-active organics in atmospheric aerosols, Top. Curr. Chem., 339, 201-259, doi:10.1007/128_2012_404, 2014.
Millet, D. B., Jacob, D. J., Turquety, S., Hudman, R. C., Wu, S., Fried, A., Walega, J., Heikes, B. G., Blake, D. R., Singh, H. B., Anderson, B. E., and Clarke, A. D.: Formaldehyde distribution over North America: Implications for satellite retrievals of formaldehyde columns and isoprene emission, J. Geophys. Res., 111, D24S02, doi:10.1029/2005jd006853, 2006.

Myriokefalitakis, S., Tsigaridis, K., Mihalopoulos, N., Sciare, J., Nenes, A., Kawamura, K., Segers, A., and Kanakidou, M.: Incloud oxalate formation in the global troposphere: a 3-D modeling study, Atmos. Chem. Phys., 11, 5761-5782, doi:10.5194/acp11-5761-2011, 2011.

Ng, N. L., Kwan, A. J., Surratt, J. D., Chan, A. W. H., Chhabra, P. S., Sorooshian, A., Pye, H. O. T., Crounse, J. D., Wennberg, P. O., Flagan, R. C., and Seinfeld, J. H.: Secondary organic aerosol (SOA) formation from reaction of isoprene with nitrate radicals $\left(\mathrm{NO}_{3}\right)$, Atmos. Chem. Phys., 8, 4117-4140, doi:10.5194/acp-84117-2008, 2008.

Nguyen, T. B., Coggon, M. M., Bates, K. H., Zhang, X., Schwantes, R. H., Schilling, K. A., Loza, C. L., Flagan, R. C., Wennberg, P. O., and Seinfeld, J. H.: Organic aerosol formation from the reactive uptake of isoprene epoxydiols (IEPOX) onto nonacidified inorganic seeds, Atmos. Chem. Phys., 14, 3497-3510, doi:10.5194/acp-14-3497-2014, 2014.

Nguyen, T. B., Crounse, J. D., Teng, A. P., St. Clair, J. M., Paulot, F., Wolfe, G. M., and Wennberg, P. O.: Rapid deposition of oxidized biogenic compounds to a temperate forest, P. Natl. Acad. Sci. USA, 112, E392-E401, doi:10.1073/pnas.1418702112, 2015a.

Nguyen, T. B., Bates, K. H., Crounse, J. D., Schwantes, R. H., Zhang, X., Kjaergaard, H. G., Surratt, J. D., Lin, P., Laskin, A., Seinfeld, J. H., and Wennberg, P. O.: Mechanism of the hydroxyl radical oxidation of methacryloyl peroxynitrate (MPAN) and its pathway toward secondary organic aerosol formation in the atmosphere, Phys. Chem. Chem. Phys., 17, 17914-17926, doi:10.1039/c5cp02001h, 2015b.

Nozière, B., Dziedzic, P., and Córdova, A.: Products and kinetics of the liquid-phase reaction of glyoxal catalyzed by ammonium ions $\left(\mathrm{NH}_{4}^{+}\right)$, J. Phys. Chem. A, 113, 231-237, doi:10.1021/jp8078293, 2009.

Odum, J. R., Hoffmann, T., Bowman, F., Collins, D., Flagan, R. C., and Seinfeld, J. H.: Gas/particle partitioning and secondary organic aerosol yields, Environ. Sci. Technol., 30, 2580-2585, doi:10.1021/es950943+, 1996.

Palmer, P. I., Jacob, D. J., Fiore, A. M., Martin, R. V., Chance, K., and Kurosu, T. P.: Mapping isoprene emissions over North America using formaldehyde column observations from space, J. Geophys. Res., 108, 4180, doi:10.1029/2002jd002153, 2003.

Palmer, P. I., Abbot, D. S., Fu, T.-M., Jacob, D. J., Chance, K., Kurosu, T. P., Guenther, A., Wiedinmyer, C., Stanton, J. C., Pilling, M. J., Pressley, S. N., Lamb, B., and Sumner, A. L.: Quantifying the seasonal and interannual variability of North American isoprene emissions using satellite observations of the formaldehyde column, J. Geophys. Res., 111, D12315, doi:10.1029/2005jd006689, 2006.

Paulot, F., Crounse, J. D., Kjaergaard, H. G., Kroll, J. H., Seinfeld, J. H., and Wennberg, P. O.: Isoprene photooxidation: new insights into the production of acids and organic nitrates, Atmos. Chem. Phys., 9, 1479-1501, doi:10.5194/acp-9-1479-2009, 2009a.

Paulot, F., Crounse, J. D., Kjaergaard, H. G., Kürten, A., St Clair, J. M., Seinfeld, J. H., and Wennberg, P. O.: Unexpected epoxide 
formation in the gas-phase photooxidation of isoprene, Science, 325, 730-733, doi:10.1126/science.1172910, 2009 b.

Peeters, J., Nguyen, T. L., and Vereecken, L.: $\mathrm{HO}_{x}$ radical regeneration in the oxidation of isoprene, Phys. Chem. Chem. Phys., 11, 5935-5939, doi:10.1039/b908511d, 2009.

Peeters, J. and Müller, J.-F.: $\mathrm{HO}_{x}$ radical regeneration in isoprene oxidation via peroxy radical isomerisations. II: Experimental evidence and global impact, Phys. Chem. Chem. Phys., 12, 1422714235, doi:10.1039/c0cp00811g, 2010.

Piletic, I. R., Edney, E. O., and Bartolotti, L. J.: A computational study of acid catalyzed aerosol reactions of atmospherically relevant epoxides, Phys. Chem. Chem. Phys., 15, 18065-18076, doi:10.1039/c3cp52851k, 2013.

Pye, H. O. T., Chan, A. W. H., Barkley, M. P., and Seinfeld, J. H.: Global modeling of organic aerosol: the importance of reactive nitrogen $\left(\mathrm{NO}_{x}\right.$ and $\left.\mathrm{NO}_{3}\right)$, Atmos. Chem. Phys., 10, 1126111276, doi:10.5194/acp-10-11261-2010, 2010.

Pye, H. O. T., Pinder, R. W., Piletic, I. R., Xie, Y., Capps, S. L., Lin, Y.-H., Surratt, J. D., Zhang, Z., Gold, A., Luecken, D. J., Hutzell, W. T., Jaoui, M., Offenberg, J. H., Kleindienst, T. E., Lewandowski, M., and Edney, E. O.: Epoxide pathways improve model predictions of isoprene markers and reveal key role of acidity in aerosol formation, Environ. Sci. Technol., 47, 1105611064, doi:10.1021/es402106h, 2013.

Riedel, T. P., Lin, Y.-H., Budisulistiorini, S. H., Gaston, C. J., Thornton, J. A., Zhang, Z. F., Vizuete, W., Gold, A., and Surratt, J. D.: Heterogeneous reactions of isoprene-derived epoxides: Reaction probabilities and molar secondary organic aerosol yield estimates, Environ. Sci. Technol. Lett., 2, 38-42, doi:10.1021/ez500406f, 2015.

Rollins, A. W., Kiendler-Scharr, A., Fry, J. L., Brauers, T., Brown, S. S., Dorn, H.-P., Dubé, W. P., Fuchs, H., Mensah, A., Mentel, T. F., Rohrer, F., Tillmann, R., Wegener, R., Wooldridge, P. J., and Cohen, R. C.: Isoprene oxidation by nitrate radical: alkyl nitrate and secondary organic aerosol yields, Atmos. Chem. Phys., 9, 6685-6703, doi:10.5194/acp-9-6685-2009, 2009.

Sato, K., Nakao, S., Clark, C. H., Qi, L., and Cocker III, D. R.: Secondary organic aerosol formation from the photooxidation of isoprene, 1,3-butadiene, and 2,3-dimethyl-1,3-butadiene under high $\mathrm{NO}_{x}$ conditions, Atmos. Chem. Phys., 11, 7301-7317, doi:10.5194/acp-11-7301-2011, 2011

Saxena, P. and Hildemann, L. M.: Water-soluble organics in atmospheric particles: A critical review of the literature and application of thermodynamics to identify candidate compounds, J. Atmos. Chem., 24, 57-109, doi:10.1007/bf00053823, 1996.

Schwartz, S. E.: Mass-transport considerations pertinent to aqueous-phase reactions of gases in liquid-water clouds, in: Chemistry of Multiphase Atmospheric Systems, edited by: Jaechske, W., Springer, Heidelberg, 415-471, 1986.

Scott, C. E., Rap, A., Spracklen, D. V., Forster, P. M., Carslaw, K. S., Mann, G. W., Pringle, K. J., Kivekäs, N., Kulmala, M., Lihavainen, H., and Tunved, P.: The direct and indirect radiative effects of biogenic secondary organic aerosol, Atmos. Chem. Phys., 14, 447-470, doi:10.5194/acp-14-447-2014, 2014.

SEAC ${ }^{4}$ RS Archive: doi:10.5067/Aircraft/SEAC4RS/AerosolTraceGas-Cloud, 2015.

Song, M., Liu, P. F., Hanna, S. J., Li, Y. J., Martin, S. T., and Bertram, A. K.: Relative humidity-dependent viscosities of isoprene-derived secondary organic material and atmospheric implications for isoprene-dominant forests, Atmos. Chem. Phys., 15, 5145-5159, doi:10.5194/acp-15-5145-2015, 2015.

Stavrakou, T., Peeters, J., and Müller, J.-F.: Improved global modelling of $\mathrm{HO}_{x}$ recycling in isoprene oxidation: evaluation against the GABRIEL and INTEX-A aircraft campaign measurements, Atmos. Chem. Phys., 10, 9863-9878, doi:10.5194/acp-10-98632010, 2010.

St. Clair, J. M., Rivera-Rios, J. C., Crounse, J. D., Knap, H. C., Bates, K. H., Teng, A. P., Jørgensen, S., Kjaergaard, H. G., Keutsch, F. N., and Wennberg, P. O.: Kinetics and products of the reaction of the first-generation isoprene hydroperoxide (ISOPOOH) with OH, J. Phys. Chem. A, doi:10.1021/acs.jpca.5b06532, online first, 2015.

Sumner, A. J., Woo, J. L., and McNeill, V. F.: Model Analysis of secondary organic aerosol formation by glyoxal in laboratory studies: The case for photoenhanced chemistry, Environ. Sci. Technol., 48, 11919-11925, doi:10.1021/es502020j, 2014.

Surratt, J. D., Murphy, S. M., Kroll, J. H., Ng, N. L., Hildebrandt, L., Sorooshian, A., Szmigielski, R., Vermeylen, R., Maenhaut, W., Claeys, M., Flagan, R. C., and Seinfeld, J. H.: Chemical composition of secondary organic aerosol formed from the photooxidation of isoprene, J. Phys. Chem. A, 110, 9665-9690, doi:10.1021/jp061734m, 2006.

Surratt, J. D., Lewandowski, M., Offenberg, J. H., Jaoui, M., Kleindienst, T. E., Edney, E. O., and Seinfeld, J. H.: Effect of acidity on secondary organic aerosol formation from isoprene, Environ. Sci. Technol., 41, 5363-5369, doi:10.1021/es0704176, 2007a.

Surratt, J. D., Kroll, J. H., Kleindienst, T. E., Edney, E. O., Claeys, M., Sorooshian, A., Ng, N. L., Offenberg, J. H., Lewandowski, M., Jaoui, M., Flagan, R. C., and Seinfeld, J. H.: Evidence for organosulfates in secondary organic aerosol, Environ. Sci. Technol., 41, 517-527, doi:10.1021/es062081q, 2007 b.

Surratt, J. D., Chan, A. W. H., Eddingsaas, N. C., Chan, M., Loza, C. L., Kwan, A. J., Hersey, S. P., Flagan, R. C., Wennberg, P. O., and Seinfeld, J. H.: Reactive intermediates revealed in secondary organic aerosol formation from isoprene, P. Natl. Acad. Sci. USA, 107, 6640-6645, doi:10.1073/pnas.0911114107, 2010.

Tan, Y., Perri, M. J., Seitzinger, S. P., and Turpin, B. J.: Effects of precursor concentration and acidic sulfate in aqueous glyoxal-OH radical oxidation and implications for secondary organic aerosol, Environ. Sci. Technol., 43, 8105-8112, doi:10.1021/es901742f, 2009.

Tan, Y., Carlton, A. G., Seitzinger, S. P., and Turpin, B. J.: SOA from methylglyoxal in clouds and wet aerosols: Measurement and prediction of key products, Atmos. Environ., 44, 5218-5226, doi:10.1016/j.atmosenv.2010.08.045, 2010.

Toon, O. B. and the SEAC ${ }^{4}$ RS science team: Planning, implementation, and scientific goals of the Studies of Emissions and Atmospheric Composition, Clouds, and Climate Coupling by Regional Surveys (SEAC ${ }^{4}$ RS) field mission, J. Geosphys. Res., submitted, 2016.

Travis, K. R., Jacob, D. J., Fisher, J. A., Kim, P. S., Marais, E. A., Zhu, L., Miller, C. C., Wennberg, P. O., Crounse, J., Hanisco, T. A., Ryerson, T., Yu, K., Wolfe, G. M., Thompson, A., Mao, J., Paulot, F., Yantosca, R. M., Sulprizio, M., and Neuman, A.: $\mathrm{NO}_{x}$ emissions, isoprene oxidation pathways, and implications for surface ozone in the Southeast United States, Atmos. Chem. Phys. Discuss., submitted, 2016. 
Virtanen, A., Joutsensaari, J., Koop, T., Kannosto, J., Yli-Pirilä, P., Leskinen, J., Mäkelä, J. M., Holopainen, J. K., Pöschl, U., Kulmala, M., Worsnop, D. R., and Laaksonen, A.: An amorphous solid state of biogenic secondary organic aerosol particles, Nature, 467, 824-827, doi:10.1038/nature09455, 2010.

Volkamer, R., Martini, F. S., Molina, L. T., Salcedo, D., Jimenez, J. L., and Molina, M. J.: A missing sink for gas-phase glyoxal in Mexico City: Formation of secondary organic aerosol, Geophys. Res. Lett., 34, L19807, doi:10.1029/2007g1030752, 2007.

Volkamer, R., Ziemann, P. J., and Molina, M. J.: Secondary Organic Aerosol Formation from Acetylene $\left(\mathrm{C}_{2} \mathrm{H}_{2}\right)$ : seed effect on SOA yields due to organic photochemistry in the aerosol aqueous phase, Atmos. Chem. Phys., 9, 1907-1928, doi:10.5194/acp9-1907-2009, 2009.

Wagner, N. L., Brock, C. A., Angevine, W. M., Beyersdorf, A., Campuzano-Jost, P., Day, D., de Gouw, J. A., Diskin, G. S., Gordon, T. D., Graus, M. G., Holloway, J. S., Huey, G., Jimenez, J. L., Lack, D. A., Liao, J., Liu, X., Markovic, M. Z., Middlebrook, A. M., Mikoviny, T., Peischl, J., Perring, A. E., Richardson, M. S., Ryerson, T. B., Schwarz, J. P., Warneke, C., Welti, A., Wisthaler, A., Ziemba, L. D., and Murphy, D. M.: In situ vertical profiles of aerosol extinction, mass, and composition over the southeast United States during SENEX and SEAC ${ }^{4}$ RS: observations of a modest aerosol enhancement aloft, Atmos. Chem. Phys., 15, 7085-7102, doi:10.5194/acp-15-7085-2015, 2015.

Wang, J., Hoffmann, A. A., Park, R. J., Jacob, D. J., and Martin, S. T.: Global distribution of solid and aqueous sulfate aerosols: Effect of the hysteresis of particle phase transitions, J. Geophys. Res., 113, D11206, doi:10.1029/2007jd009367, 2008.

Waxman, E. M., Dzepina, K., Ervens, B., Lee-Taylor, J., Aumont, B., Jimenez, J. L., Madronich, S., and Volkamer, R.: Secondary organic aerosol formation from semi- and intermediate-volatility organic compounds and glyoxal: Relevance of $\mathrm{O} / \mathrm{C}$ as a tracer for aqueous multiphase chemistry, Geophys. Res. Lett., 40, 978982, doi:10.1002/grl.50203, 2013.

Xu, L., Kollman, M. S., Song, C., Shilling, J. E., and Ng, N. L.: Effects of $\mathrm{NO}_{x}$ on the volatility of secondary organic aerosol from isoprene photooxidation, Environ. Sci. Technol., 48, 22532262, doi:10.1021/es404842g, 2014.

Xu, L., Guo, H., Boyd, C. M., Klein, M., Bougiatioti, A., Cerully, K. M., Hite, J. R., Isaacman-VanWertz, G., Kreisberg, N. M., Knote, C., Olson, K., Koss, A., Goldstein, A. H., Hering, S. V., de Gouw, J., Baumann, K., Lee, S.-H., Nenes, A., Weber, R. J., and Ng, N. L.: Effects of anthropogenic emissions on aerosol formation from isoprene and monoterpenes in the southeastern United States, P. Natl. Acad. Sci. USA, 112, 37-42, doi:10.1073/pnas.1417609112, 2015.
Yu, Karen, Jacob, Daniel J., Fisher, Jenny A., Kim, Patrick S., Marais, Eloise A., Miller, Christopher C., Travis, Katherine R., Zhu, Lei, Yantosca, Robert M., Sulprizio, Melissa P., Cohen, Ron C., Dibb, Jack E., Fried, Alan, Mikoviny, Tomas, Ryerson, Thomas B., Wennberg, Paul O., and Wisthaler, Armin: Sensitivity to grid resolution in the ability of a chemical transport model to simulate observed oxidant chemistry under high-isoprene conditions, Atmos. Chem. Phys. Discuss., doi:10.5194/acp-2015980, in review, 2016.

Zhang, H., Surratt, J. D., Lin, Y. H., Bapat, J., and Kamens, R. M.: Effect of relative humidity on SOA formation from isoprene/NO photooxidation: enhancement of 2-methylglyceric acid and its corresponding oligoesters under dry conditions, Atmos. Chem. Phys., 11, 6411-6424, doi:10.5194/acp-11-6411-2011, 2011.

Zhang, H., Parikh, H. M., Bapat, J., Lin, Y. H., Surratt, J. D., and Kamens, R. M.: Modelling of secondary organic aerosol formation from isoprene photooxidation chamber studies using different approaches, Environ. Chem., 10, 194-209, doi:10.1071/en13029, 2013.

Zhang, Q., Jimenez, J. L., Canagaratna, M. R., Allan, J. D., Coe, H., Ulbrich, I., Alfarra, M. R., Takami, A., Middlebrook, A. M., Sun, Y. L., Dzepina, K., Dunlea, E., Docherty, K., DeCarlo, P. F., Salcedo, D., Onasch, T., Jayne, J. T., Miyoshi, T., Shimono, A., Hatakeyama, S., Takegawa, N., Kondo, Y., Schneider, J., Drewnick, F., Borrmann, S., Weimer, S., Demerjian, K., Williams, P., Bower, K., Bahreini, R., Cottrell, L., Griffin, R. J., Rautiainen, J., Sun, J. Y., Zhang, Y. M., and Worsnop, D. R.: Ubiquity and dominance of oxygenated species in organic aerosols in anthropogenically-influenced Northern Hemisphere midlatitudes, Geophys. Res. Lett., 34, L13801, doi:10.1029/2007g1029979, 2007.

Zhu, L., Jacob, D., Mickley, L., Kim, P. S., Fisher, J., Travis, K., Yu, K., Yantosca, R. M., Sulprizio, M., Fried, A., Hanisco, T., Wolfe, G., Abad, G. G., Chance, K., De Smedt, I., and Yang, K.: Indirect validation of new OMI, GOME-2, and OMPS formaldehyde (HCHO) retrievals using SEAC ${ }^{4} \mathrm{RS}$ data, in preparation, 2016. 